\title{
Distribution, Microfabric, and Geochemical Characteristics of Siliceous Rocks in Central Orogenic Belt, China: Implications for a Hydrothermal Sedimentation Model
}

\author{
Hongzhong Li, ${ }^{1,2}$ Mingguo Zhai, ${ }^{1}$ Lianchang Zhang, ${ }^{1}$ Le Gao, ${ }^{2,3}$ \\ Zhijun Yang, ${ }^{2,3}$ Yongzhang Zhou, ${ }^{2,3}$ Junguo $\mathrm{He}^{2,3}$ \\ Jin Liang, ${ }^{2,3}$ Liuyu Zhou, ${ }^{2,3}$ and Panagiotis Ch. Voudouris ${ }^{4}$ \\ ${ }^{1}$ Key Laboratory of Mineral Resources, Institute of Geology and Geophysics, Chinese Academy of Sciences, Beijing 100029, China \\ ${ }^{2}$ Guangdong Provincial Key Lab of Geological Processes and Mineral Resource Survey, Guangzhou 510275, China \\ ${ }^{3}$ Department of the Earth Sciences, Sun YAT-SEN University, Guangzhou 510275, China \\ ${ }^{4}$ Department of Mineralogy-Petrology, University of Athens, Athens 15784, Greece
}

Correspondence should be addressed to Hongzhong Li; lihongzhong01@aliyun.com and Junguo He; zsu_iam001@sina.cn

Received 3 May 2014; Accepted 9 June 2014; Published 22 July 2014

Academic Editor: Grzegorz Racki

Copyright (C) 2014 Hongzhong Li et al. This is an open access article distributed under the Creative Commons Attribution License, which permits unrestricted use, distribution, and reproduction in any medium, provided the original work is properly cited.

Marine siliceous rocks are widely distributed in the central orogenic belt (COB) of China and have a close connection to the geological evolution and metallogenesis. They display periodic distributions from Mesoproterozoic to Jurassic with positive peaks in the Mesoproterozoic, Cambrian-Ordovician, and Carboniferous-Permian and their deposition is enhanced by the tensional geological settings. The compressional regimes during the Jinning, Caledonian, Hercynian, Indosinian, and Yanshanian orogenies resulted in sudden descent in their distribution. The siliceous rocks of the Bafangshan-Erlihe ore deposit include authigenic quartz, syn-depositional metal sulphides, and scattered carbonate minerals. Their $\mathrm{SiO}_{2}$ content (71.08-95.30\%), Ba (42.45-503.0 ppm), and $\Sigma \operatorname{REE}(3.28-19.75 \mathrm{ppm})$ suggest a hydrothermal sedimentation origin. As evidenced by the $\mathrm{Al} /(\mathrm{Al}+\mathrm{Fe}+\mathrm{Mn}), \mathrm{Sc} / \mathrm{Th},(\mathrm{La} / \mathrm{Yb})_{N}$, and $(\mathrm{La} / \mathrm{Ce})_{N}$ ratios and $\delta$ Ce values, the studied siliceous rocks were deposited in a marginal sea basin of a limited ocean. We suggest that the Bafangshan-Erlihe area experienced high- and low-temperature stages of hydrothermal activities. The hydrothermal sediments of the former stage include metal sulphides and silica, while the latter was mainly composed of silica. Despite the hydrothermal sedimentation of the siliceous rocks, minor terrigenous input, magmatism, and biological activity partly contributed to geochemical features deviating from the typical hydrothermal characteristics.

\section{Introduction}

Siliceous rocks are widely distributed in the central orogenic belt (COB), China, and display a close relationship with the hydrothermal metallogenesis. In the $\mathrm{COB}$, the distribution of siliceous rocks records the tectonic evolution of the whole orogenic belt [1-4]. It has been previously suggested that the siliceous rocks were originated from hydrothermal precipitation having a close relationship with the metallogenesis of many large hydrothermal ore deposits in China [5-7], especially those belonging to the SEDEX-type $[8,9]$. The siliceous strata in the above hydrothermal ore deposits in
China are either ore-hosting rocks or country rocks $[1,10-$ 15].

The siliceous rocks of the $\mathrm{COB}$ and their relationship with the tectonic evolution and metallogenesis are still poorly described. According to [16], the distribution characteristics of siliceous rocks in the tectonic belts between two blocks have a close relationship with the tectonic evolution, inner dynamic, and metallogenesis [16]. The relationship between siliceous rocks and their associated orebodies has been discussed by $[1,4,12,17]$. In addition, there are hydrothermal ore deposits in the $\mathrm{COB}$, whose associated siliceous rocks are of hydrothermal genesis $[1,4,17]$, but these ore deposits 

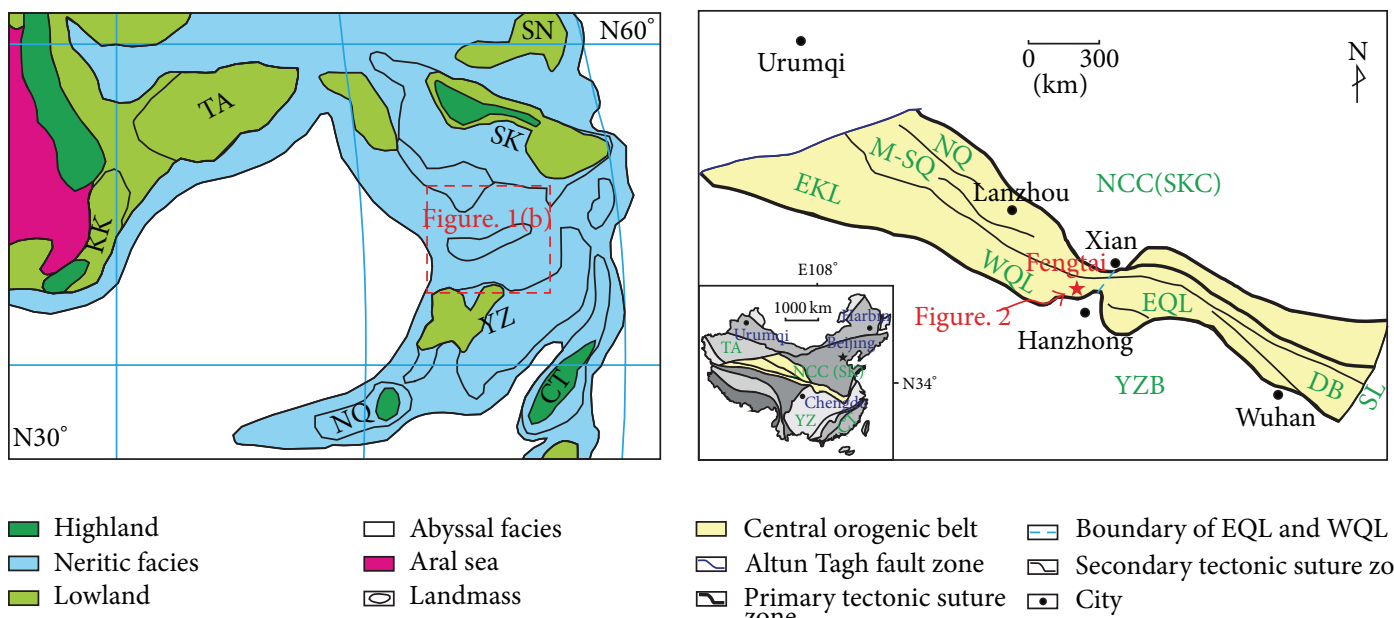

(a)

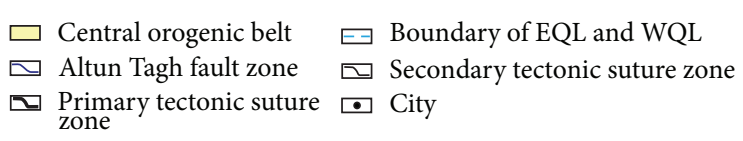

(b)

FIGURE 1: Geographical map and geological sketch of COB and the associated area ((a) -reconstruction map of the Middle-Permian paleocontinents [28]; (b) - geological framework of central orogenic belt [29, 30], TA: Tarim, KK: Karakum, SN: Sonnen, SK: Sino-Korean, YZ: Yangtze, NQ: Northern Qiangtang, CT: Cathaysian, EKL: Eastern Kunlun, M-SQ: Middle-South Qilian, NQ: North Qilian, WQL: Western Qinling, EQL: Eastern Qinling, SKC: Sino-Korean craton, YZB: Yangtze block, and DB:Dabie orogenic belt).

are regarded to be of orogenic type and formed during the orogeny [12]. As one of the typical hydrothermal ore deposits in the COB, the Bafangshan-Erlihe SEDEX deposit is a stratabound $\mathrm{Cu}-\mathrm{Pb}-\mathrm{Zn}$ deposit with siliceous strata hosting and surrounding ores [5]. The siliceous rocks and associated mineralisation are slightly modified during subsequent orogenic processes $[15,18,19]$, resulting in redistribution of metal sulphides in fissures, as commonly observed in orogenic type deposits [20]. The characteristics of BafangshanErlihe ore deposit fit to both hydrothermal sedimentary ore deposits [11] and orogenic ore deposits [12], but no obvious evidence can directly exclude metallogenic sources from either hydrothermal seafloor (and subseafloor) precipitation or deposition from orogenic fluids. Thus, the distribution and compositional characteristics of the siliceous rocks may help clarifying the geological evolution and metallogenesis in the area.

The Bafangshan-Erlihe SEDEX deposit is of importance to understand the mechanism of hydrothermal water evolution in the paleo-ocean. It is located in the FengxianTaibai (or Fengtai) area [5], and is characterized by close relationships between the metallogenesis and deposition of siliceous strata. Previous work $[1,4]$ considered the siliceous rocks of the Bafangshan-Erlihe ore deposit to be of hydrothermal genesis, however ignoring the mineralogical characteristics, evolution mechanism of the hydrothermal water, and relationship between these siliceous rocks and their associated metal sulphides. In addition, the mechanism of hydrothermal convection necessary for the deposition of the siliceous rocks remained uncertain, and whether there are similarities to the published literature $[21,22]$ has to be confirmed. The aim of this paper is to study the characteristics of temporal and spatial distribution of the siliceous rocks in the COB, their microfabric and geochemical characteristics, and to present a model that incorporates the contribution of different geological processes during the deposition of hydrothermal silica and sulphide.

\section{Geological Setting and Petrological Characteristics}

2.1. Geological Setting. The COB has a complex tectonic evolution evidenced by the diversity in the eastern and western Qinling orogenic belts. The mainland of the present China is originated from the matching of several Neopaleozoic landmasses (Figure 1(a)). These blocks are Sino-Korean, Sonnen, Northern Qiangtang, Cathaysian, Tarim, Yangtze, and so forth. The COB is located in the middle of China and separated the Sino-Korean craton and Yangtze block on its north and south (Figure 1(b)). This orogenic belt is mainly made up of Kunlun, Qilian, Qinling, Dabie, and Sulu orogenic belts and passes through the provinces of Qinghai, Gansu, Shanxi, Henan, and Anhui, China, in northwest direction (Figure $1(\mathrm{~b})$ ). The main feature of the $\mathrm{COB}$ is the Qinling collisional orogenic belt [23]. The geological evolution of the Qingling orogenic belt can be divided into the formation of Precambrian basement from Neoarchaean to Mesoproterozoic $\left(\mathrm{Ar}_{3}-\mathrm{Pt}_{2}\right)$, evolution of plate tectonics from Neoproterozoic to Middle Triassic $\left(\mathrm{Pt}_{3}-\mathrm{T}_{2}\right)$, and intracontinental orogeny from Mesozoic (Late Triassic) to Cenozoic $\left(\mathrm{Mz}\left(\mathrm{T}_{3}\right)-\mathrm{Kz}\right)$ [24]. Although the whole ocean basin of western Qinling starts from the Early Cambrian rift basin and ends up with the Triassic orogeny [25], the tectonic diversity of geological evolution contributed to the subdivision of a western section and an eastern section within the Qinling orogenic belt $[26,27]$. The three tectonic cycles of openingclosing for the western Qinling are Early Cambrian Early Devonian, Middle Devonian Late Carboniferous, and Early Permian $\sim$ Late Triassic [27], while the two tectonic phases of opening-closing for eastern Qinling are Early Cambrian 


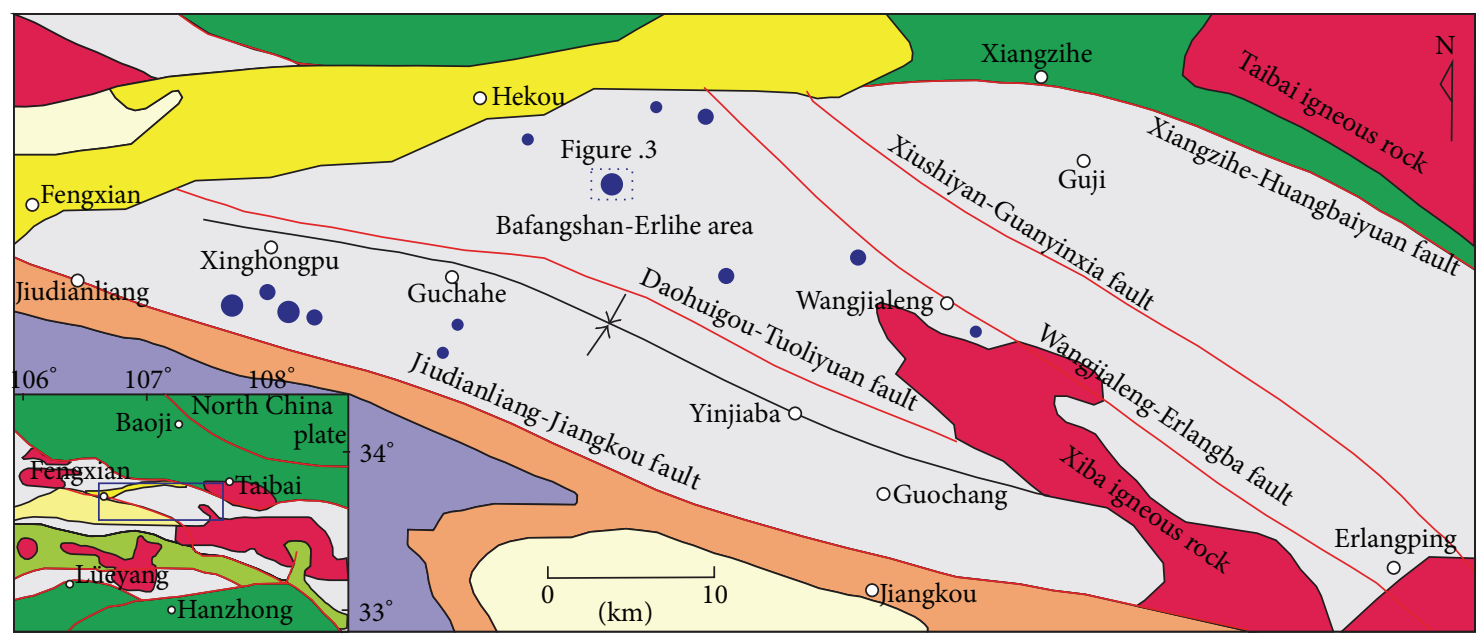

Mesozoic igneous rock

Permian phyllite, limestone, carbonaceous siliceous rock

Silurian clastic rock, siliceous limestone, phyllite, slate * Synclinorum

Cretaceous clastic rock

Carboniferous phyllite, limestone, siliceous rock
Precambrian volcanic rock and sedimentary rock

$\square$ Geological boundury

$\square$ Triassic microclastic rock

$\square$ Devonian clastic rock, carbonate rock, siliceous rock

$\square$ Fault

$\cdots \mathrm{Pb}-\mathrm{Zn}$ ore deposit

Figure 2: Geological sketch-map of the Fengxian-Taibai ore concentration area (after-[33]).

$\sim$ Late Silurian and Early Devonian Late Triassic [26]. It is considered that the ocean basin of the $\mathrm{COB}$ is neritic in the Middle Permian [28], but whether there is a similar geographical pattern in the Devonian will be examined through the present study of the siliceous rocks from the Fengtai area.

The Fengtai metallogenic area is located in the central part of the western Qinling orogenic belt. In the Fengtai metallogenic area (Figure 2), there are many polymetallic ore deposits, in the Bafangshan-Erlihe, Bijiashan, Dengjiashan, Qiandongshan, Yinmusi, Shoubanya, and Fengya areas. The tectonic frame is trending in NW direction as expressed by the Guchahe-Yinjiaba multiple downfolds and large faults (e.g., Xiushiyan-Guanyinxia, Wangjialeng-Erlangba, and Daohuigou-Tuoliyuan faults). The Fengtai area is located in the pull-apart basin of the northern region of Qinling microplate, whose southern and northern boundaries are Liuba peel thrust faults and the Shangzhou-Danfeng fault, respectively. Additionally, it is a secondary basin controlled by cross-basin synfaults [31], which are named FengxianFengzhen-Shanyang and Jiudianliang-Zhenan-Banyanzhen faults $[1,32]$.

There is a diversity of sedimentary strata in the Fengtai area. The siliceous rocks associated with the metallogenesis of the Bafangshan-Erlihe ore deposit are mainly concentrated in the Middle-Upper Devonian strata (Figure 2). The Middle-Upper Devonian strata include clastic rocks of the Wangjialeng Formation, carbonate rocks of the Gudaoling Formation, metamorphic debris with interlayers of carbonate rocks of the Xinghongpu Formation, and fine-grained clastic rocks of Jiuliping Formation.
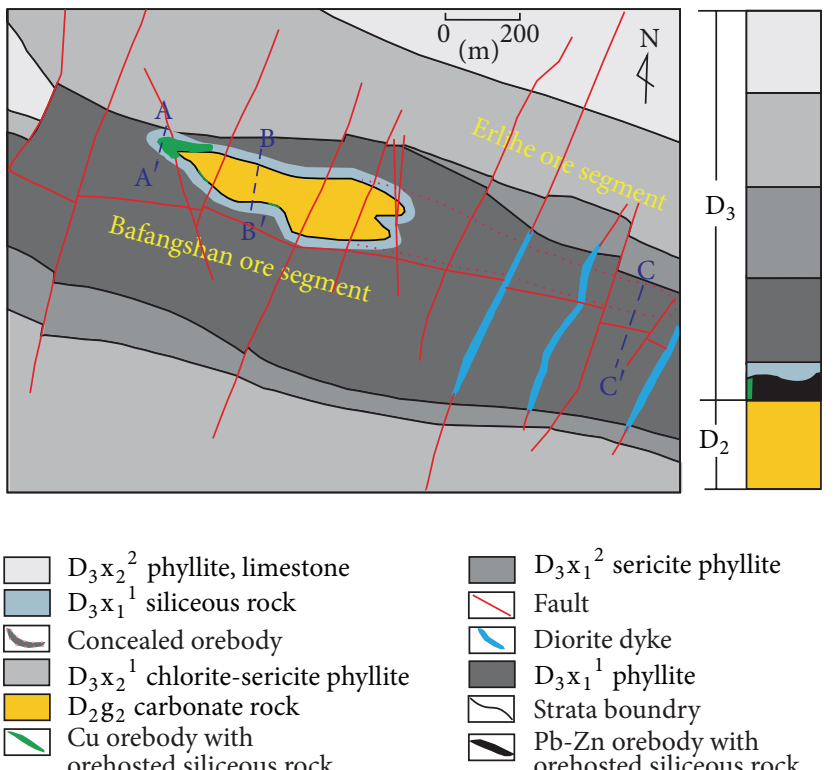

$\mathrm{D}_{3} \mathrm{x}_{2}{ }^{2}$ phyllite, limestone

$\mathrm{D}_{3} \mathrm{x}_{1}{ }^{1}$ siliceous rock

Concealed orebody

$\mathrm{D}_{3} \mathrm{x}_{2}{ }^{1}$ chlorite-sericite phyllite

$\mathrm{D}_{2} \mathrm{~g}_{2}$ carbonate rock

Cu orebody with

orehosted siliceous rock

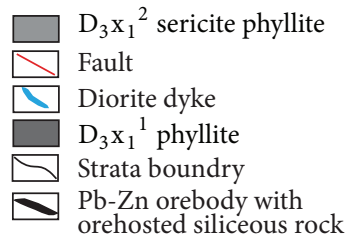

FIGURE 3: Geological map of the Bafangshan-Erlihe area (after-[33]).

2.2. Geology of Ore Deposit. The Bafangshan-Erlihe ore deposit is one of the significant hydrothermal ore deposits in the Fengtai metallogenic area located in the northwestern Fengtai basin (Figure 1). The strata belong to the Middle Devonian Gudaoling Formation (D2) and to the Upper Devonian Xinghongpu Formation D3 (Figure 3).

The Upper Devonian Xinghongpu Formation is made up of clastic rocks (siltstones and sandstones) with some foliated 
limestones [32, 34]. The strata of the Xinghongpu Formation are divided into three different lithological sections as follows: the first section of the Xinghongpu Formation includes arenaceous phyllite; the second section of the Xinghongpu Formation is comprised of carbon-bearing phyllite and sericitic phyllite; the third section is mainly composed of banded lamellar limestone and calcitic-sericitic-phyllite. In the bottom of the first section, there are ferrodolomite, sericitic phyllite, and siliceous rocks, which were the country rocks of the $\mathrm{Cu}-\mathrm{Pb}-\mathrm{Zn}$ orebody.

The Middle Devonian Gudaoling Formation occupies the entire Bafangshan-Erlihe ore deposit (Figure 3). This formation extends downward to the lower part, beneath the earth's surface, to make up the core of the Bafangshan-Erlihe anticlinal. This formation is divided into two parts: the first part is a clastic series including sandstones and shales and the second part is composed of carbonate rocks.

The hydrothermal sedimentary sequence is located in the interface between the Middle Devonian Gudaoling Formation and the Upper Devonian Xinghongpu Formation. This sedimentary sequence is composed of siliceous rocks, siliceous ferrodolomites, silicified limestones, and limestones. The stratum of the siliceous rocks, ranging from $1 \mathrm{~m}$ to $30 \mathrm{~m}$, belongs to the ore-bearing strata. There are boudinaged siliceous rocks and aggregates of siliceous ankerite in the orebearing strata. The siliceous rocks are exposed on the surface at the Bafangshan area whereas they extend downwards to the Erlihe area. In addition, some of the orebodies are hosted in limestones or ferrodolomites.

The Bafangshan-Erlihe ore region is intensively folded and faulted (Figure 3). The $\mathrm{Cu}-\mathrm{Pb}-\mathrm{Zn}$ orebodies are controlled by the Bafangshan-Erlihe anticline. There are two types of faults: the normal faults, striking NNE-SSW and NNW-SSE, are widely distributed across the study area with an angle of dip of $70^{\circ}$; the compression-shear faults, striking $\mathrm{EW}$, with hades ranging from $48^{\circ}$ to $73^{\circ}$. The area is characterized by a weak magmatic activity related to the emplacement of some dikes along NE-striking normal faults. The dykes include quartz-porphyries and quartz-diorite-porphyries.

\subsection{Distribution of Orebody. The $\mathrm{Cu}-\mathrm{Pb}-\mathrm{Zn}$ ore deposits} in the Bafangshan-Erlihe area are controlled by anticlines (Figure 3) [32, 34]. The Bafangshan-Erlihe ore deposit is divided into two segments, which are located in the Bafangshan and Erlihe areas. Because of denudation at the top of the anticlines, the orebodies of the Bafangshan segment are exposed at the surface. In the core of the anticlines, the ore strata are distributed with the shape of an irregular circle around the limestone. They stretch eastward and become underground toward the Erlihe ore area. In the Erlihe area, the orebodies are concealed at a depth of up to 800 meters. The proven orebodies are mostly developed on the arch bend of the anticlines in longitudinal profile (Figures 3 and 4). Orebodies are stratabound and generally contact with the adjoining country rocks conformably. The primary orebody is consistent with the construction of the anticlines, and it is more than 2300 meters in length and ranges from 100 meters to 300 meters in width [34]. On the incline, the primary

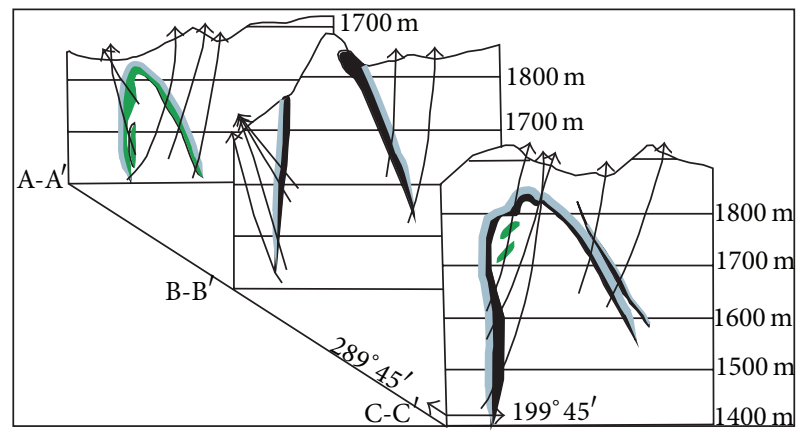

$\mathrm{Cu}$ ore body with ore-hosted siliceous rock

$\mathrm{Pb}-\mathrm{Zn}$ ore body with ore-hosted siliceous rock

Discontiguous siliceous rock, some parts feebly mineralized

FIGURE 4: Cross-sections of ore body and siliceous rock in the Bafangshan-Erlihe $\mathrm{Cu}-\mathrm{Pb}-\mathrm{Zn}$ ore deposit. For location see Figure 3 (After-[12]).

orebodies stretch downwards and become narrower from east to west.

There are obvious horizontal and vertical mineralization characteristics (Figure 4). At the Bafangshan ore deposit the ore grade decreases with depth $[34,35]$, thus, all copper, lead and zinc are distributed in the upper part of the deposit. Along strike, the Bafangshan ore deposit generally extends from east to west and can be grouped into the east, middle, and west parts without clear mineralization boundaries between them [35]. The eastern part is characterized by mineralised zones of copper, lead and zinc, dominated by chalcopyrite, sphalerite, and galena, respectively. The middle part is mainly composed of lead and zinc sulphides (e.g. galena and sphalerite). The main mineralization in the western part consists of chalcopyrite with traces of galena and sphalerite.

2.4. Petrological Characteristics. In the Bafangshan-Erlihe ore deposit, mineralization is hosted in siliceous rock and ferrodolomite breccias. The breccias are cemented by chalcopyrite (Figure 5(a)), galena, sphalerite, and pyrite. Some of the ferrodolomite-bearing siliceous rocks are oxidised and display alternating layers of siliceous rocks and ferrodolomites (Figure 5(b)). The ores exhibit brecciated, stockwork, and lamellar structures. The pure siliceous rocks, without mineralisation, are grey, compacted, and hard with brecciated, massive (Figure 5(c)), and banded structures (Figure 5(b)). Microscopically, the siliceous rocks are composed of finely crystalline quartz, forming close-packed or interlocking textures (Figure 5(d)), which are similar to slightly recrystallized siliceous rocks of hydrothermal genesis [36]. Minor idiomorphic carbonate minerals are also present in the siliceous rocks (Figure 5(e)). In addition, there are also some recrystallized quartz grains with much larger grain sizes (Figure 5(f)), surrounded by the finely crystalline quartz grains in the matrix. 


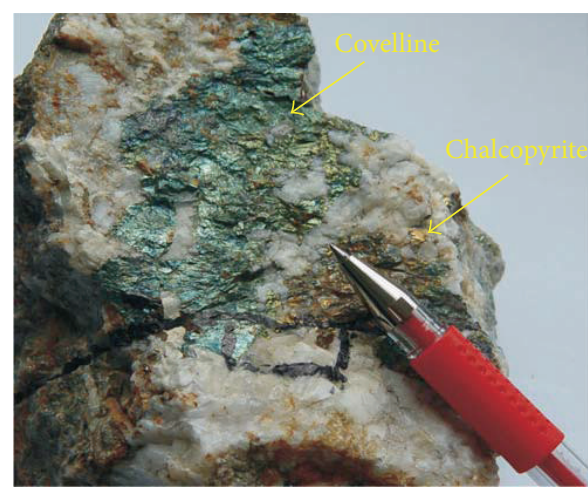

(a)

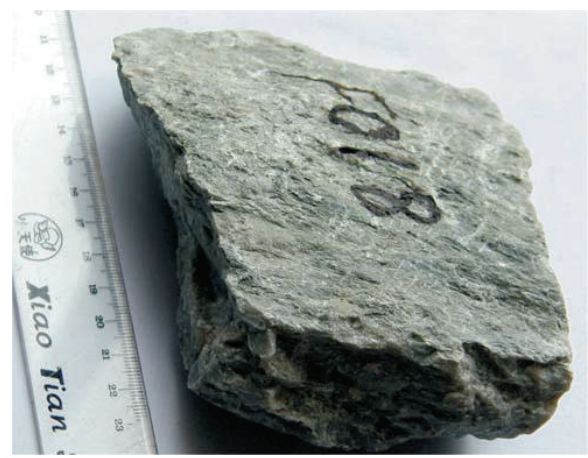

(c)

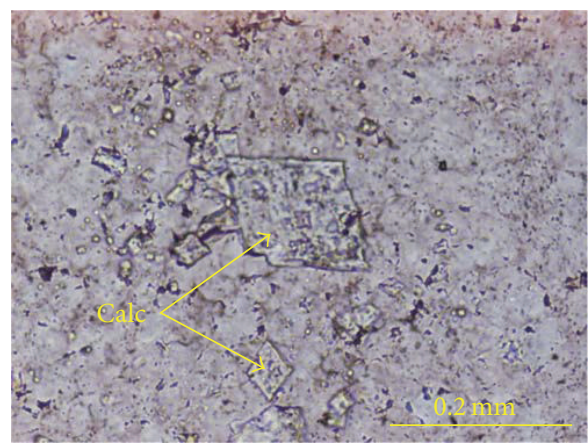

(e)

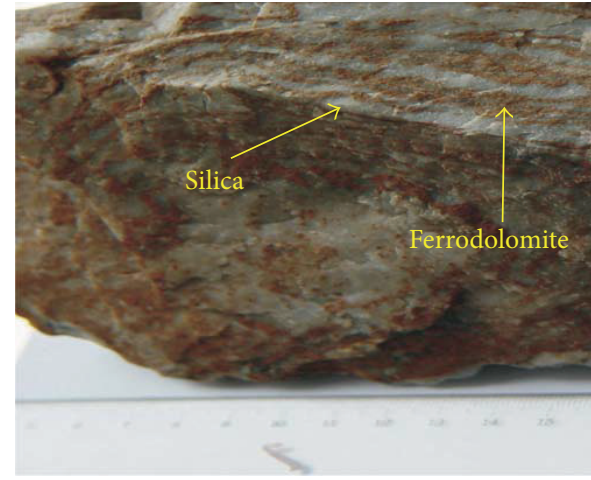

(b)

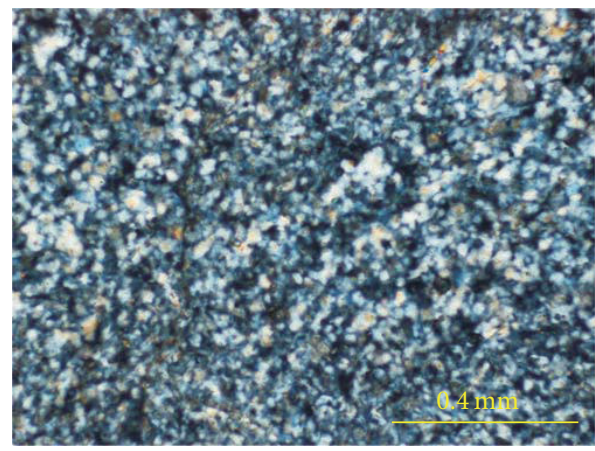

(d)

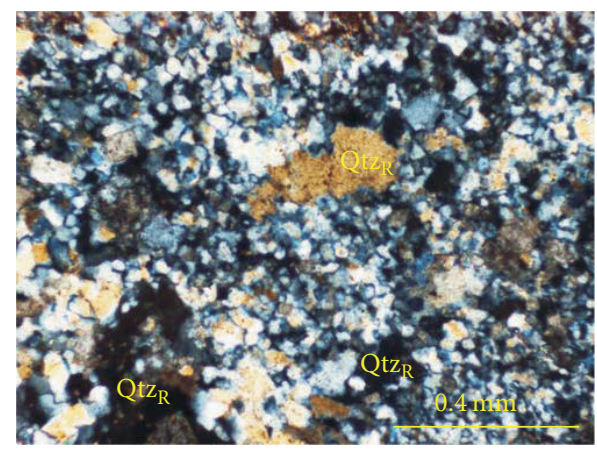

(f)

FIGURE 5: Ores and siliceous rocks from the Bafangshan-Erlihe ore deposit ((a) copper ore; (b) ferrodolomite-bearing siliceous rocks with lamellar structures, the lamellae of the ferrodolomite were oxidised; (c) pure siliceous rock; (d) finely crystalline siliceous rock under parallel nicols; (e) idiomorphic calcite in parallel nicols; (f) recrystallized quartz in crossed nicols; Calc-Calcite, $\mathrm{Qtz}_{\mathrm{R}}$-recrystallized quartz).

\section{Samples and Experiments}

During the pretreatment processes, fresh samples (including ore-hosting siliceous rocks and pure siliceous rocks without mineralization) of Bafangshan-Erlihe polymetallic ore deposit were selected, cleaned in ultrapure water, dried, and then divided into two groups, namely, one polished into thin sections $(\leq 0.03 \mathrm{~mm})$ and the other crushed into grains of $0.3 \mathrm{~cm}$-equivalent spherical diameter in a clean corundum jaw-breaker. A subsample from the latter group was selected, cleaned, redried, and ground to $0.075 \mathrm{~mm}$ diameter particles in an agate ball mill (NO. XQN-500x4). Additionally, all the ore-hosting siliceous rocks were repeatedly separated from the ore to ensure their purification.

The pretreatment and analysis of each sample's major elements were carried out in Guilin's Research Institute of Geology and Mineral Resource Test Centre, and the results are shown in Table 1 . The $\mathrm{SiO}_{2}$ content was analysed by potassium hexafluorosilicate titration to an accuracy of between $1 \%$ and $1.5 \%$. The $\mathrm{Al}_{2} \mathrm{O}_{3}$ constituents were analysed with ultraviolet spectrophotometry (to contents below $1 \%$ by mass, using instrument type UV-120-02, at an accuracy of $0.5 \%$ to $1 \%$ ) or by EDTA titration (for contents above $1 \%$, to an accuracy of $1.5 \%$ ). The $\mathrm{Na}_{2} \mathrm{O}, \mathrm{K}_{2} \mathrm{O}$, and 


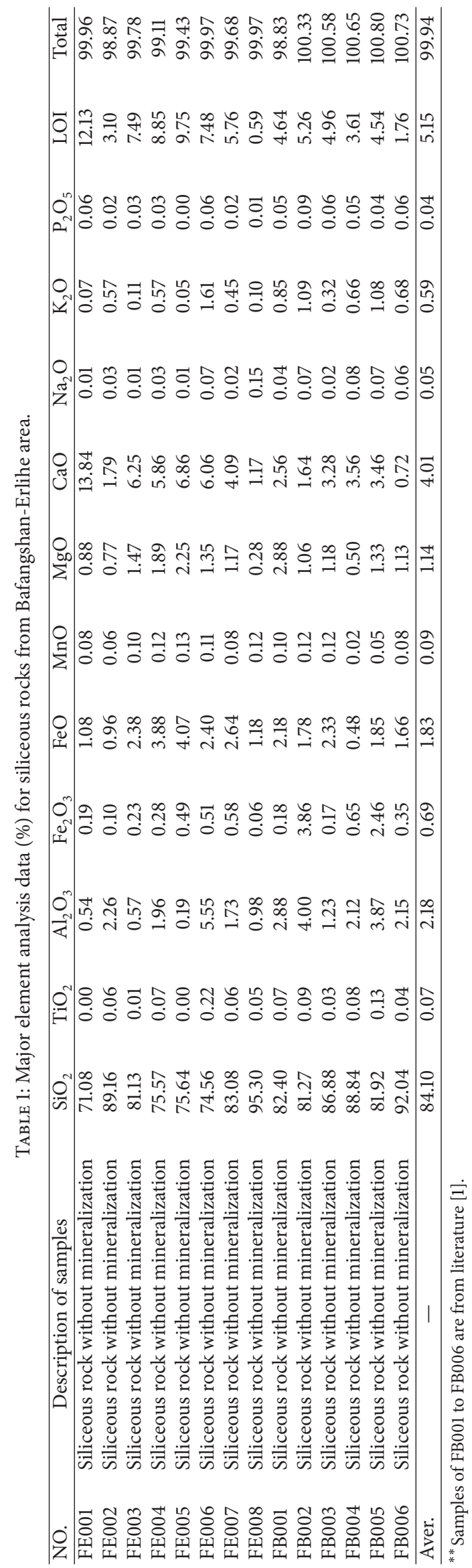


$\mathrm{MgO}$ constituents were analysed by atomic absorption spectroscopy (instrument type HITACHI Z-5000, to an accuracy of $1 \%$ ). The $\mathrm{CaO}$ was analysed by atomic absorption spectroscopy (for contents below 10\%, using a HITACHIZ-5000 instrument, with an accuracy of $1 \%$ ) or by EDTA titration method (for contents above $10 \%$, at an accuracy of $1.5 \%$ ). The $\mathrm{P}_{2} \mathrm{O}_{5}$ was analysed by ultraviolet spectrophotometry (for contents below 1\%, using instrument type UV-12002 , with an accuracy of between $0.5 \%$ and $1 \%$ ). The $\mathrm{TiO}_{2}$ and $\mathrm{MnO}$ constituents were analysed by inductively coupled plasma optical emission spectrometry (ICP-OES) with instruments iCAP_6300_RADIAL and iCAP_6301_RADIAL, with accuracies between $0.5 \%$ and $1.5 \%$. The $\mathrm{FeO}$ and $\mathrm{Fe}_{2} \mathrm{O}_{3}$ contents were obtained by potassium dichromate titration.

An inductively coupled plasma mass spectrometer (ICPMS, Instrument Model: PE Elan6000) with an analytical accuracy of $1 \%$ to $3 \%$ was used to test for trace and rare earth elements. The test solution was prepared by acid-soluble dissolution and the experiment was performed in accordance with standard protocols. Samples weighing $100 \mathrm{mg}$ were placed in a sealed Teflon container and $1 \mathrm{~mL}$ of concentrated $\mathrm{HF}$ and $0.3 \mathrm{~mL}$ of $1: 1 \mathrm{HNO}_{3}$ were added. Following ultrasonic oscillation, the samples were placed on a hot plate at $150^{\circ} \mathrm{C}$ and then evaporated to dryness, remixed with the same amount of $\mathrm{HF}$ and $\mathrm{HNO}_{3}$, and heated under confinement for a week (at approximately $100^{\circ} \mathrm{C}$ ). After evaporation and dissolution in $2 \mathrm{~mL}$ of $1: 1$ nitric acid, the sample was added to an Rh internal standard, diluted to 1/2000th of its original concentration, and tested in the PE Elan6000 ICP-MS.

Pretreatment for Raman spectroscopy and X-ray diffraction (XRD) analyses was performed in the Guangdong Provincial Key Laboratory of Geological Processes and Mineral Resource Survey. Raman analysis was performed in the State Key Laboratory of Geological Processes and Mineral Resources, where the Renishaw RM-1000 invia microconfocal instrument was used for the Raman experiments, with excitation by the $514.5 \mathrm{~nm}$ line of an $\mathrm{Ar}^{+}$ laser. Raman spectra were recorded to a resolution of $1 \mathrm{~cm}^{-1}$ from $50 \mathrm{~cm}^{-1}$ to $1800 \mathrm{~cm}^{-1}$. An XRD analysis was carried out in the laboratory of the College of Chemistry and Chemical Engineering of Sun Yat-Sen University. XRD data were collected with an X-ray powder diffractometer (instrument type: D/Max-2200 vpc) in reflection focusing geometry mode $(\mathrm{Cu} \mathrm{K} \alpha$ radiation; $40 \mathrm{kV} / 30 \mathrm{~mA}$, scanning speed: $0.12 \mathrm{~s}$ per step, step length: $0.02^{\circ}$, continuous scanning mode). Over a range of $5^{\circ} \leq$ scanning angle $\leq 100^{\circ}$, the data were postprocessed by JADE-5.0 software based on the eight highest peaks for the identification of several mineral types.

The Scanning Electron Microscope (SEM) and Energy Disperse Spectroscopy (EDS) analysis were carried out by the State Key Laboratory of China's University of Geosciences. The ring scanning electron microscopy instrument was a Quanta 200F environmental scanning electron microscopyenergy spectrum-electron backscatter diffraction system (SEM-EDS) with a resolution of $3.5 \mathrm{~nm}$ and a magnification of 7 to $1,000,000$.

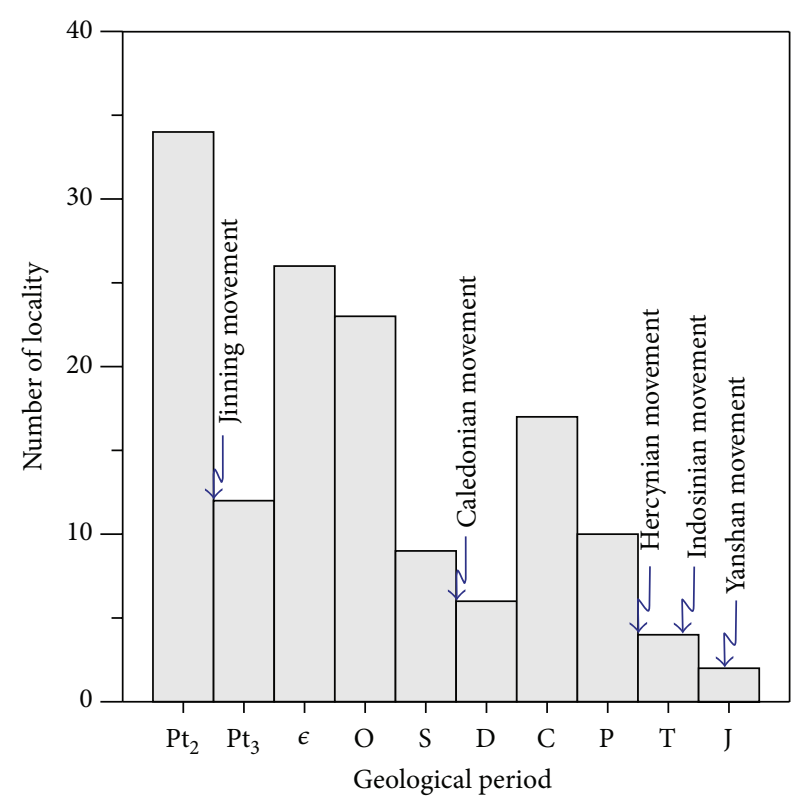

FIgURE 6: Column diagram of number for localities of siliceous rocks in the $\mathrm{COB}$ (data were calculated from literatures [32, 37-40]).

\section{Analytical Results}

4.1. Distribution Characteristics. The COB, trending in a NW direction, mainly includes the provinces of Qinghai, Gansu, Shanxi, Henan, and Anhui, China (Figure 1(b)). In the present study, the numbers and localities of siliceous rocks were calculated from these five provinces based on location and formation as the main parameters. The localities of the siliceous rocks were calculated from the regional geology of Zhejiang, Jiangxi, Hunan, Guangdong, and Guangxi provinces $[32,37-40]$. In locations, where there is a uniform distribution of siliceous rocks within diverse strata, these siliceous rocks were separated on the basis of Formation unit. Additionally, the Precambrian strata were divided into Mesoproterozoic and Neoproterozoic (Sinian) strata according to the literatures [32, 37-40].

4.1.1. Temporal Distribution. In the COB, the marine siliceous rocks display a periodic quantitative distribution from Mesoproterozoic to Jurassic. There were positive peaks of their distribution number in the Mesoproterozoic, Cambrian Ordovician, and Carboniferous $\sim$ Permian (Figure 6). The highest distribution of siliceous rocks occurs during the Mesoproterozoic, possibly related with the sustained breakup of Columbia supercontinent with a relatively long geological history $[41,42]$. The distribution numbers of siliceous rocks increased suddenly at the beginning of Cambrian, which quite agreed with the beginning of collapse of the Qinling orogenic belt [27]. Another sudden increase in their distribution number started from the beginning of Carboniferous, which agreed well with the extensional tectonic setting of the whole Qinling orogenic belt [26, 27]. From Mesoproterozoic to Jurassic, there were several sudden decreases in the distribution number of the siliceous rocks, 
which started from the beginning of Sinian, Permian, and Triassic, respectively. In the previous study [16, 37-40], the cratonisation of Rodinia continent took place between Mesoproterozoic and Neoproterozoic, and was contributed by the Jinning orogeny. The Caledonian orogeny took place in Late Silurian, in accordance with the decline in distribution number of siliceous rocks in Silurian. Additionally, there was a sudden decrease in their distribution number in Triassic, which is in accordance with the Hercynian orogeny at the end of Devonian. During the geological evolution of COB, the extensional tectonics of different tectonic cycles started from the beginning of Cambrian and Middle Devonian [26, 27], which quite agreed with the sudden increase in distribution numbers of siliceous rocks. Collision of continental plates during the Jinning, Caledonian and Hercynian movements, resulted in compressional regimes and a sudden decrease in distribution numbers of siliceous rocks. The siliceous rocks faded away since the Hercynian movements at the end of Permian, as well as in the following Indosinian and Yanshanian movements. The marine siliceous rocks disappeared since the end of Jurassic due to the regression of the whole COB. Thus, the geological setting was tensional in the tectonic eras of Caledonian (from Sinian to Late Silurian) and Hercynian (from Devonian to Late Permian) periods, when the siliceous rocks had the largest distribution number with the widest distribution. On contrary, the Jinning, Caledonian, Hercynian, Indosinian, and Yanshanian movements contributed to compressional setting and resulted in negative peaks of distribution numbers for the siliceous rocks with smaller distribution scale. According to this, the widest distributions of siliceous rocks agreed with the tensional setting, whereas the decreasing numbers of siliceous rock were attributed by the compressional settings. Previous studies show there is periodic distribution of the siliceous rocks in the Qinling orogenic belt [25], which quite agree with the present study. So, the siliceous rocks were preferential to develop more widely in tensional settings in the $\mathrm{COB}$ and decreased quantitatively due to the compressional settings.

4.1.2. Spatial Distribution. The siliceous rocks were mainly located in the border area of suture zones (Figure 7). The siliceous rocks are widely distributed in the central area of China, mainly within the $\mathrm{COB}$ and its adjacent areas (Figure 7). Because there was a clear geological diversity between eastern and western Qinling orogenic belt [26, 27], the $\mathrm{COB}$ was divided into eastern section (including eastern Qinling and Dabie orogenic belts) and western section (including western Kunlun, Qilian, and Western Qinling orogenic belts). The siliceous rocks are widely distributed in the Precambrian strata of the $\mathrm{COB}$ without a clear diversity between eastern and western sections (Figure 8(a)). In the Eopaleozoic strata (Figure 8(b)), the siliceous rocks are extensively distributed mainly in the eastern COB. The distribution of Neopaleozoic siliceous rocks is relatively weak (Figure 8(c)) mainly in the western COB. Finally, the Mesozoic siliceous rocks was very weakly and sporadically distributed in both eastern and western sections (Figure 8(d)). According to the aforementioned, the siliceous rocks are

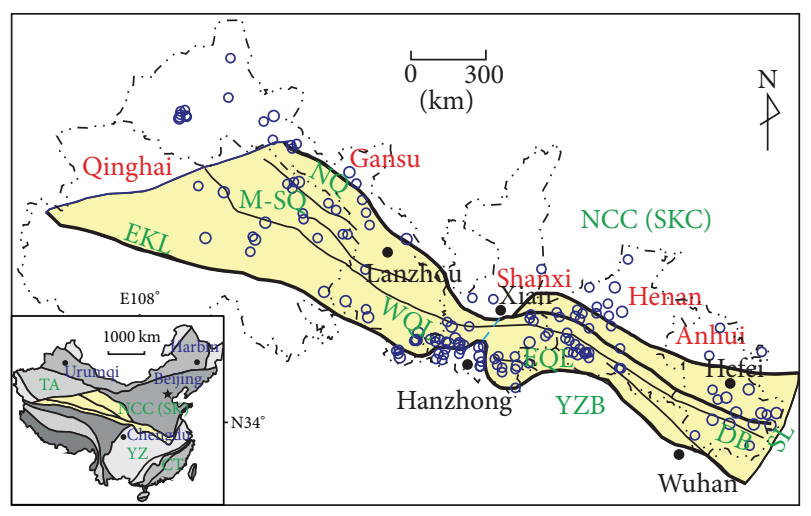

$$
\begin{array}{ll}
\text { Central orogenic belt } & -- \text { Boundary of EQL and WQL } \\
\text { Primary tectonic suture zone } & 0 \text { Siliceous rock } \\
\text { Secondary tectonic suture zone } & \bullet \text { City } \\
\text { Altun Tagh fault zone } & \square . . \text { Provincial boundary }
\end{array}
$$

FIgURE 7: Spatial distribution of total siliceous rocks in the COB (EKL: eastern Kunlun; M-SQ: Middle-South Qilian; NQ: North Qilian; WQL: Western Qinling; EQL: Eastern Qinling; SKC: SinoKorean craton; YZB: Yangtze block; DB: Dabie orogenic belt; Data sources: [32, 37-40]).

variously distributed in time and space along the $\mathrm{COB}$ : they are concentrated along the suture zones, mainly extending in Caledonian and Hercynian strata in the eastern and western sections of COB respectively. During tectonic evolution, the suture zones underwent extensional stress with many normal faults facilitating magma emplacement and transport of hydrothermal fluids [16, 43]. In the COB, siliceous rocks with a more preponderant distribution became younger from the eastern section to the western section, which is possibly attributed to the compressional setting of the eastern section and tensional setting of the western section due to the Neopaleozoic expanding of the paleo-tethys ocean [27]. Additionally, the collisional orogeny during the Indosinian and Yanshanian movements contributed to compressional settings and therefore resulted in the quantitative reduce of siliceous rocks in the Mesozoic. In summary, the siliceous rocks were mainly developed in tensional settings with a preferential distribution next to the suture zones.

4.2. Major and Trace Elements. Geochemical information (e.g. major-, trace- and rare earth element data) of the analysed siliceous rocks from the Bafangshan-Erlihe ore deposit, as well as the data from [1], used to examine their sedimentary depositional environment, genesis and geological context, is summarized below.

(1) The major elemental analysis results and geochemical indices for the siliceous rocks are listed in Tables 1 and 2. The geochemical characteristics of major elements indicated the following.

(a) A hydrothermal genesis of the siliceous rocks is suggested according to the major element characteristics with their formation process influenced by biological activities. The $\mathrm{SiO}_{2}$ content of the siliceous rocks ranges from $71.08 \%$ 


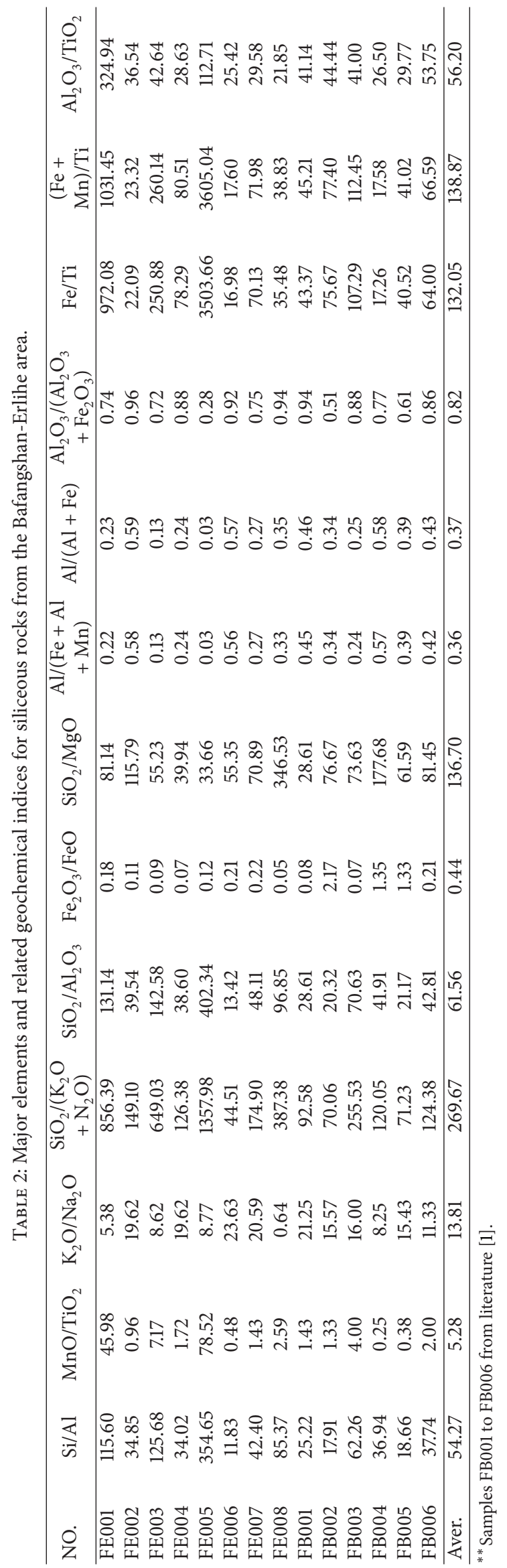



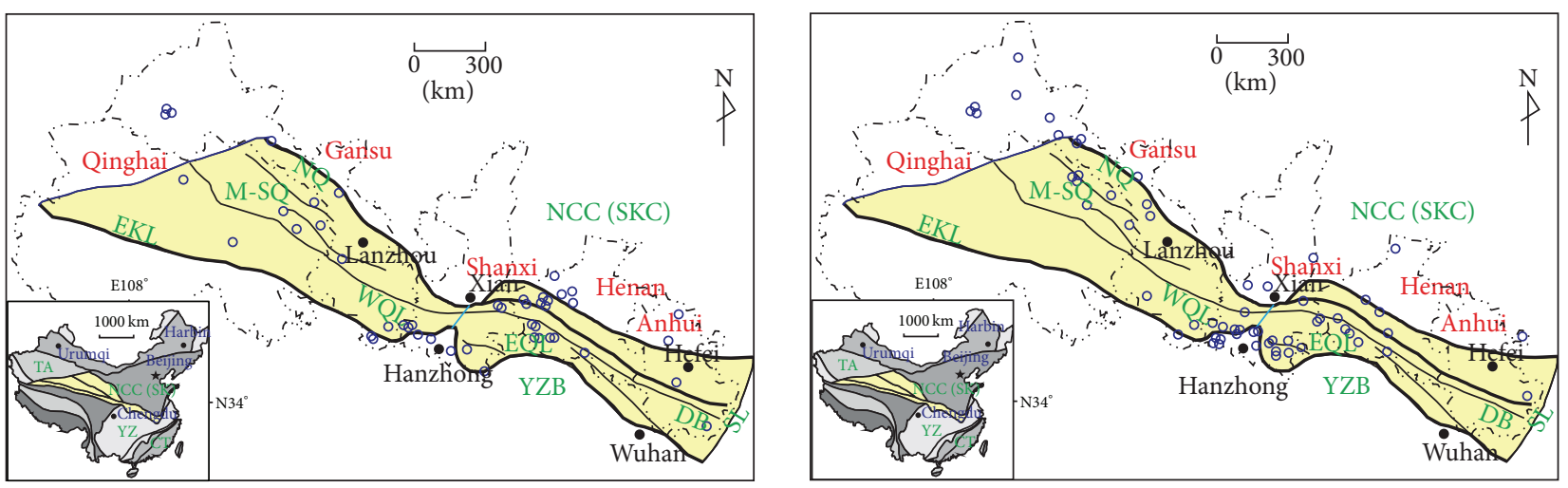

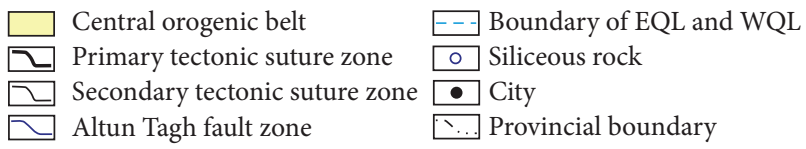

(a)

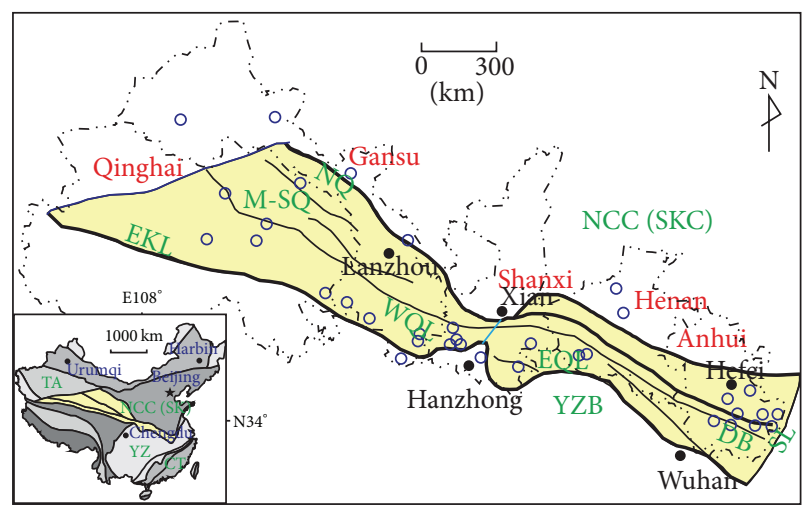

Central orogenic belt

$\square$ Primary tectonic suture zone
$\square$ Secondary tectonic suture zone

Altun Tagh fault zone

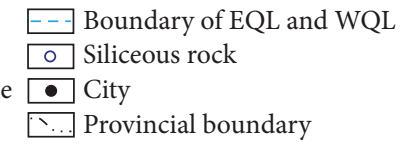

(c)

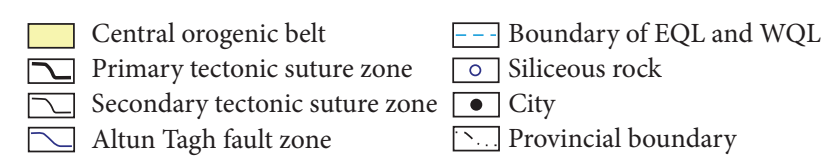

(b)

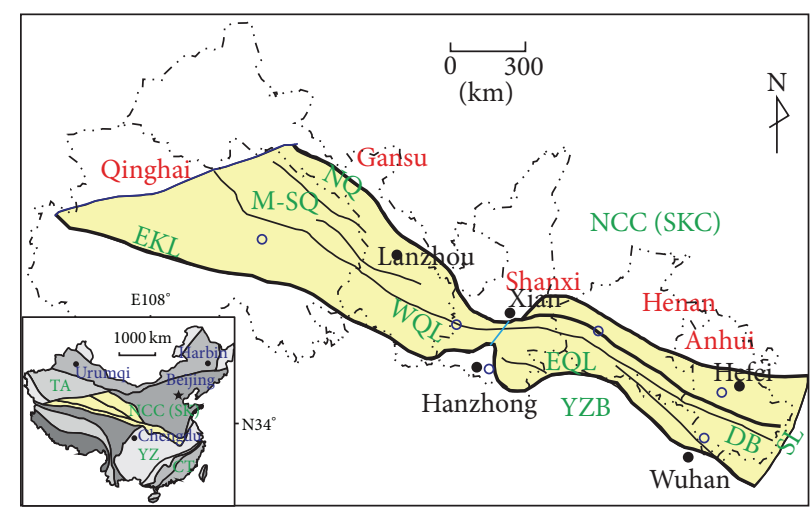

Central orogenic belt $\quad E--$ Boundary of EQL and WQL

Primary tectonic suture zone $\quad 0$ Siliceous rock

Secondary tectonic suture zone $\bullet$ City

Altun Tagh fault zone $\quad$ \... Provincial boundary

(d)

FIGURE 8: Distribution of siliceous rocks in central orogenic belt of China ((a): Precambrian; (b): Eopaleozoic; (c): Neopaleozoic; (d): Mesozoic; EKL: eastern Kunlun, M-SQ: Middle-South Qilian; NQ: North Qilian; WQL: Western Qinling; EQL: Eastern Qinling; SKC: SinoKorean craton; YZB: Yangtze block; DB: Dabie orogenic belt; Data sources: [32, 37-40]).

to $95.30 \%$ with an average of $84.10 \%$. The $\mathrm{Si} / \mathrm{Al}$ ratios range between 11.83 and 125.68, which are lower than that of pure siliceous rock with ratios usually in the range from 80 to 1400 [46]. The $\mathrm{Al} /(\mathrm{Al}+\mathrm{Fe}+\mathrm{Mn})$ ratios range from 0.03 to 0.58 , which are consistent with that of typical hydrothermal siliceous rock of below 0.4 [47]. Taking into account that $\mathrm{MgO}$ is depleted in modern ocean ridges and was zero in the hydrothermal water at $350^{\circ} \mathrm{C}$ from the East Pacific [48], the $\mathrm{MgO}$ content of the analysed siliceous rocks $(0.15 \%$ to $2.88 \%)$ is higher than that of pure hydrothermal siliceous rocks. In addition, the $(\mathrm{Fe}+\mathrm{Mn}) / \mathrm{Ti}$ ratios of the siliceous rock varies from 15.59 to 1031.45 , which is consistent with that of typical hydrothermal sediments (higher than $20 \pm 5$ [49]). The $\mathrm{Fe}_{2} \mathrm{O}_{3} / \mathrm{FeO}$ ratios range from 0.01 to 2.17 and are lower than that of the siliceous rocks of hydrothermal genesis (typically $0.51[50])$. These characteristics, as well as the associated geochemical discrimination diagrams of $\mathrm{Al}_{2} \mathrm{O}_{3}-\mathrm{SiO}_{2}$ (Figure 9(a)) and Mn-Al-Fe (Figure 9(b)), strongly support their genesis by hydrothermal sedimentation. Moreover, the siliceous rocks plotted in the $\mathrm{Fe}_{2} \mathrm{O}_{3} / \mathrm{FeO}-\mathrm{SiO}_{2} / \mathrm{Al}_{2} \mathrm{O}_{3}$ and $\mathrm{SiO}_{2} /\left(\mathrm{K}_{2} \mathrm{O}+\mathrm{Na}_{2} \mathrm{O}\right)-\mathrm{MnO} / \mathrm{TiO}_{2}$ diagrams indicated biological influences during their formation processes (Figures 9(c) and $9(\mathrm{~d}))$.

(b) The siliceous rocks of the Bafangshan-Erlihe ore deposit were formed in a marginal sea basin. According to [54], the $\mathrm{Al} /(\mathrm{A} 1+\mathrm{Fe}+\mathrm{Mn})$ ratios of siliceous rocks are diverse depending upon sedimentary processes, and they decrease from 0.619 in the continental margin to 0.319 in oceanic basins or islands, with a lower value 0.00819 at the mid-ocean ridge. This gradual reduction showed the 


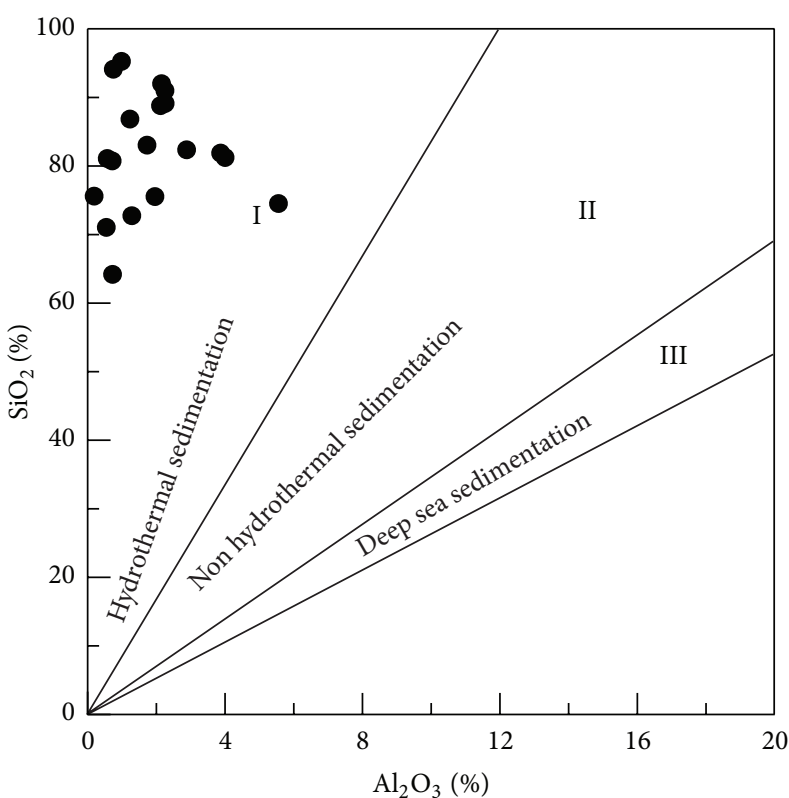

(a)

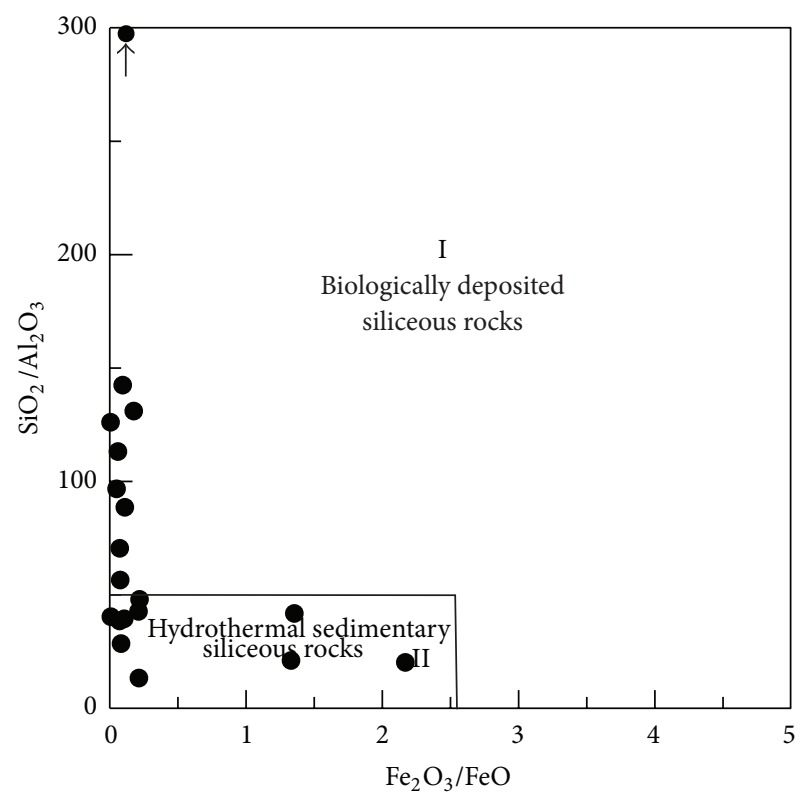

(c)

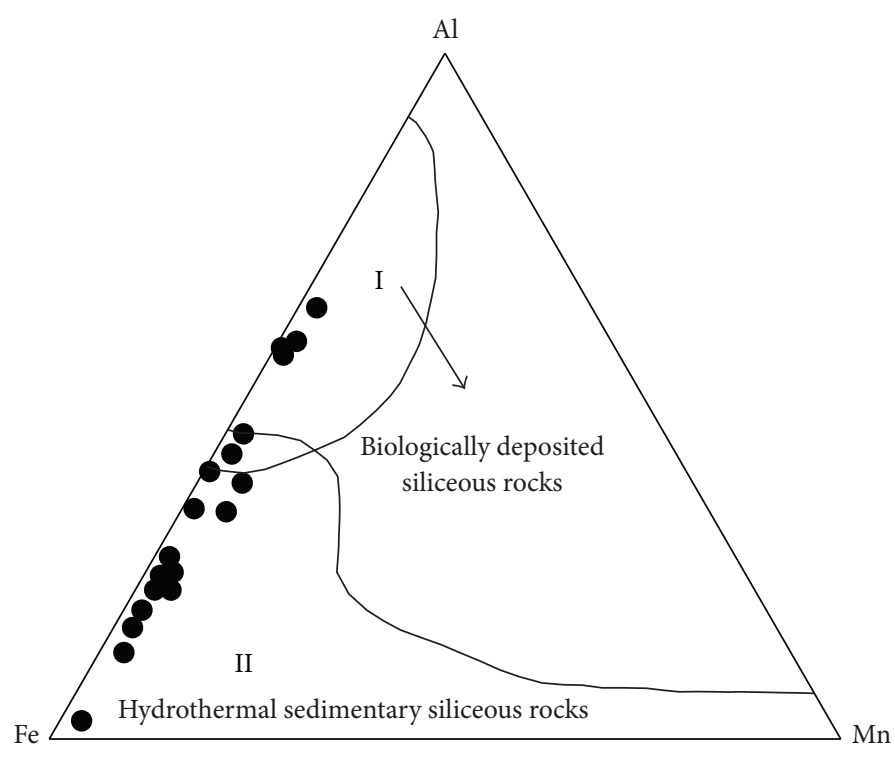

(b)

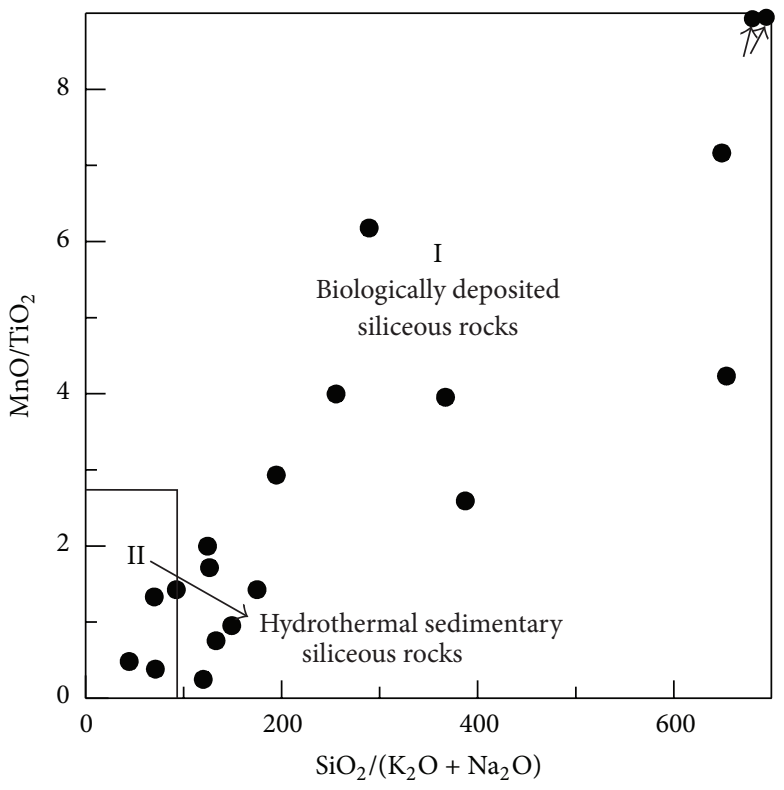

(d)

FIGURE 9: Major element discrimination diagrams supporting hydrothermal and biological processes for the genesis of siliceous rocks of the Bafangshan-Erlihe area (After: (a)—[51]; (b) - [52]; (c); (d) - [53]).

progressive influences of hydrothermal precipitation. The $\mathrm{Al} /(\mathrm{Al}+\mathrm{Fe}+\mathrm{Mn})$ ratios of the studied siliceous rocks range from 0.03 to 0.59 , which are approximately equal to that of siliceous rocks from ocean basins or continental margins. The contents of terrigenous $\mathrm{Al}$ and $\mathrm{Ti}$ are higher at the continental margin, and they decrease with distance from the marginal sea. The $\mathrm{MnO} / \mathrm{TiO}_{2}$ ratios range from 0.25 to 45.98 , which is higher than that of typical samples at the continental margin with ratios below 0.5 at the continental margin [52]. In addition, the $\mathrm{Al} /(\mathrm{Al}+\mathrm{Fe})$ ratios range from
0.03 to 0.59 , which is lower than that of the bedded siliceous rocks along the continental margin [48]. The $\mathrm{Al}_{2} \mathrm{O}_{3} /\left(\mathrm{Al}_{2} \mathrm{O}_{3}\right.$ $+\mathrm{Fe}_{2} \mathrm{O}_{3}$ ) ratios range from 0.51 to 0.96 , which is close to that of typical siliceous rock from marginal seas [53]. The above characteristics agree with the associated discrimination diagram (Figure 10).

(c) There was no obvious volcanic activity during the precipitation of hydrothermal silica. The $\mathrm{K}_{2} \mathrm{O} / \mathrm{Na}_{2} \mathrm{O}$ ratios for the analysed siliceous rocks range from 0.64 to 23.63 , which is much higher than that of the siliceous rocks deposited 


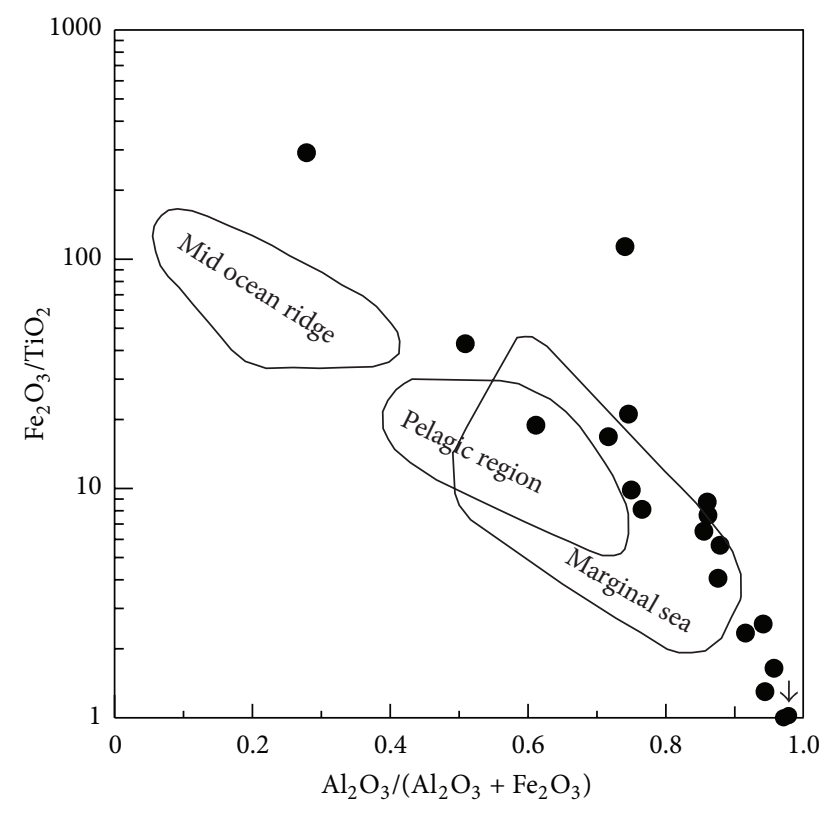

Figure 10: $\mathrm{Fe}_{2} \mathrm{O}_{3} / \mathrm{TiO}_{2}$ versus $\mathrm{Al}_{2} \mathrm{O}_{3} /\left(\mathrm{Al}_{2} \mathrm{O}_{3}+\mathrm{Fe}_{2} \mathrm{O}_{3}\right)$ discrimination diagram indicating the formation environment of the siliceous rocks of the Bafangshan-Erlihe area (After [53]).

by submarine volcanism [48]. The $\mathrm{SiO}_{2} /\left(\mathrm{K}_{2} \mathrm{O}+\mathrm{Na}_{2} \mathrm{O}\right)$ ratios of the siliceous rocks ranged from 44.51 to 856.39 , which is much higher than that of the siliceous rocks from chemical deposition related to volcanic eruptions [55]. The $\mathrm{SiO}_{2} / \mathrm{Al}_{2} \mathrm{O}_{3}$ ratios and the $\mathrm{SiO}_{2} / \mathrm{MgO}$ ratios range from 13.42 to 142.58 and from 28.61 to 649.33 respectively, which is much higher than that of siliceous rock related to magmatism, with $\mathrm{SiO}_{2} / \mathrm{Al}_{2} \mathrm{O}_{3}<13.7$ [14]. The $\mathrm{SiO}_{2} / \mathrm{MgO}$ ratios range from 28.61 to 649.33 , which is much higher than that of typical siliceous rocks related to magmatism [14]. Despite the fact, that, there was no obvious volcanic activity during their formation process, some analysed siliceous rocks plot in the category related to volcanism (in Figure 11). This may indicate a magmatic contribution related to the deep faults.

(2) The analytical results of trace elements are listed in Table 3. Trace element geochemistry indicates the following.

(a) The siliceous rocks were originated from hydrothermal precipitation. The Ba content of the siliceous rock ranges from $42.45 \mathrm{ppm}$ to $503.00 \mathrm{ppm}$ with an average of $196.64 \mathrm{ppm}$ and is between that of the MORB (12.00 ppm [57, 58]) and the crustal rocks (707 ppm [59]). The $U$ ranges from $0.07 \mathrm{ppm}$ to $1.53 \mathrm{ppm}$, with an average of $0.48 \mathrm{ppm}$, which is also between that of the MORB $(0.10 \mathrm{ppm}[57,58])$ and the crustal rocks (1.30 ppm [59]). These values are similar to those of hydrothermal sedimentary siliceous rocks and contrast from those from terrestrial sediment [60]. The U/Th ratios range from 0.07 to 4.91 , which is slightly lower than that of hydrothermal sediments [61]. The $\mathrm{Ba} / \mathrm{Sr}$ ratios range from 0.14 to 25.97 , which is in accordance with that of hydrothermal siliceous rocks $(\mathrm{Ba} / \mathrm{Sr}>1$ [62]). Additionally, a hydrothermal genesis of the siliceous rocks is supported from

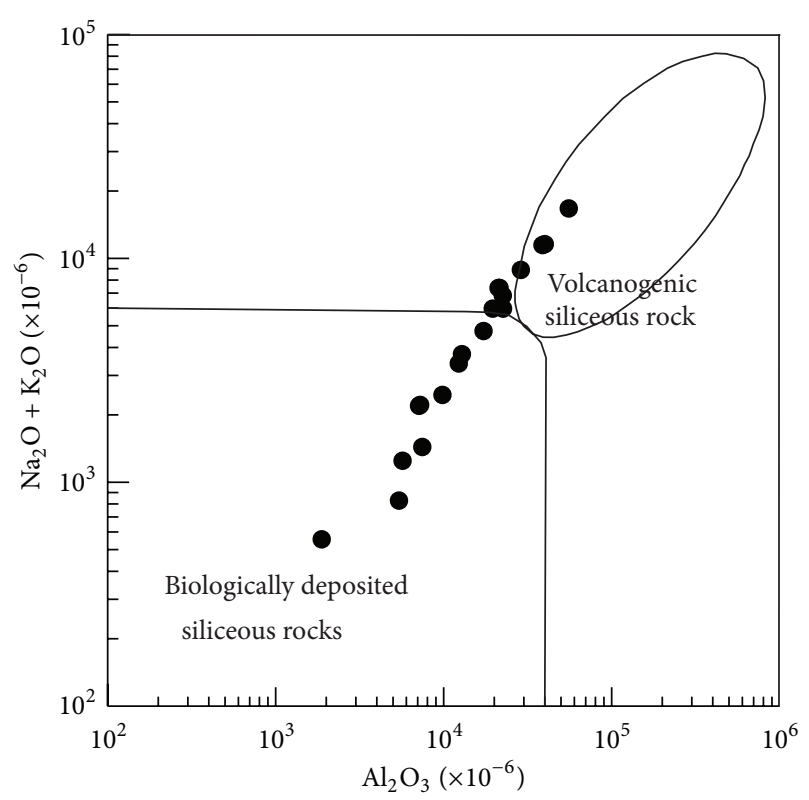

FIGURE 11: Major element discrimination diagram indicating biological and volcanic processes for the genesis of the Bafangshan-Erlihe area (After-[56]).

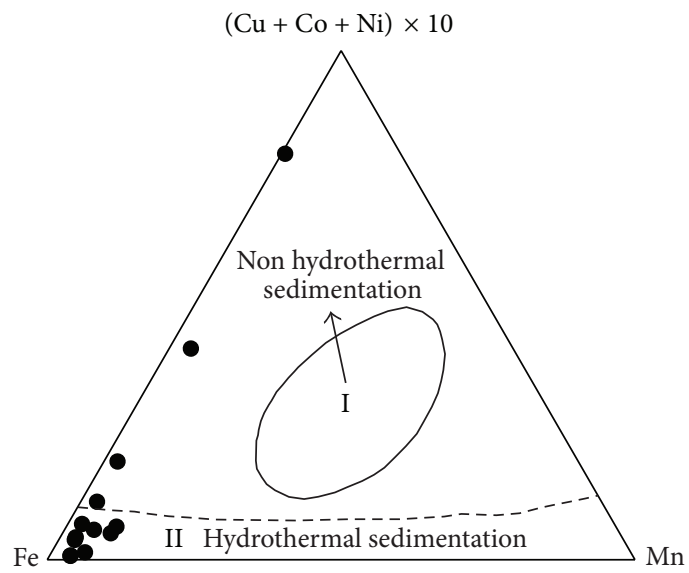

FIgURE 12: Trace element discrimination diagram indicating mostly hydrothermal genesis for siliceous rocks from the BafangshanErlihe area (After-[63]).

the discrimination diagram of $\mathrm{Mn}-(\mathrm{Cu}+\mathrm{Co}+\mathrm{Ni}) \times 10-\mathrm{Fe}$ (Figure 12).

(b) The siliceous rocks were deposited in a continental abyssal environment. The $\mathrm{Sc} / \mathrm{Th}$ ratios of the siliceous rocks range from 0.10 to 13.85 , which agree well with that of the siliceous rocks formed in the continental margin [61]. The $\mathrm{U} / \mathrm{Th}$ ratios range from 0.07 to 4.91 , which denote a depositional environment that was remote from the mainland [61]. The $\mathrm{V} /(\mathrm{V}+\mathrm{Ni})$ ratios range from 0.09 to 0.72 , which suggests that the deposition occurred in an oxygen-rich environment with $\mathrm{V} /(\mathrm{V}+\mathrm{Ni})<0.46$ [64]. The $\mathrm{Sr} / \mathrm{Ba}$ ratios range from 0.04 to 6.95 with an average of 0.95 , which indicate an abyssal sea or stagnant shallow sea [65]. In the discrimination diagram 


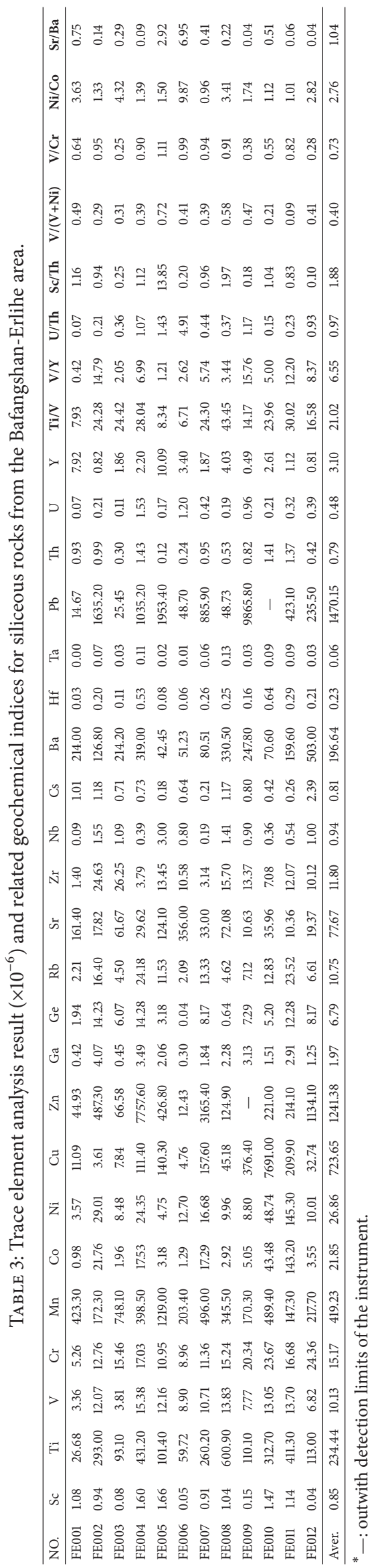




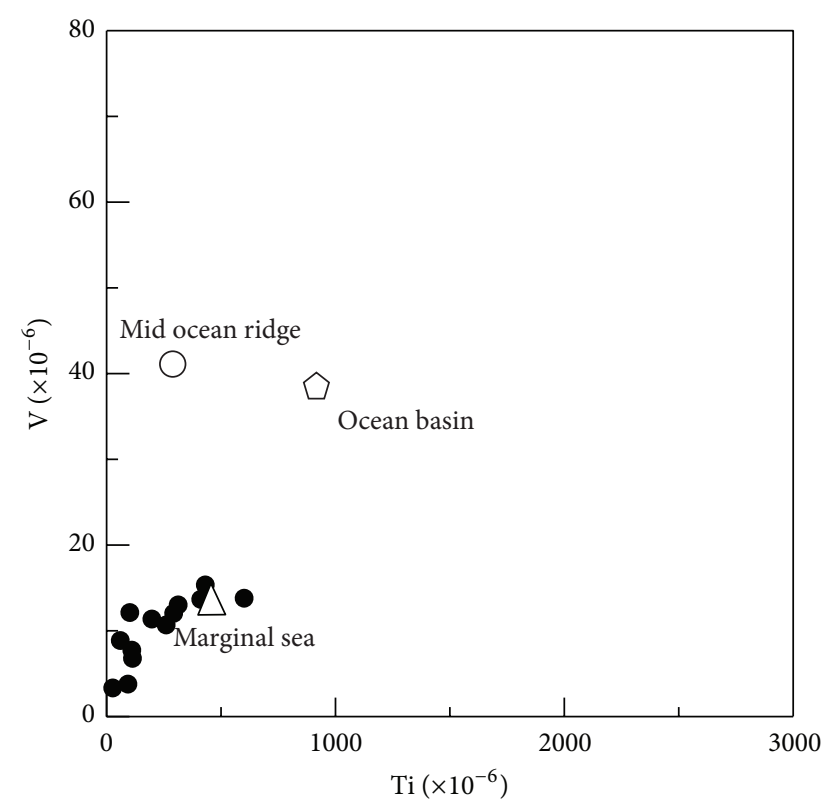

FIGURE 13: Trace element discrimination diagram demonstrating formation environment at a marginal sea basin for the siliceous rocks of the Bafangshan-Erlihe area (After-[46]).

of Ti-V, the siliceous rocks plot into the category of marginal sea (Figure 13).

(c) There was slight influence from the mafic magmatism. According to [64], the $\mathrm{V} / \mathrm{Cr}>2$ and $\mathrm{Ni} / \mathrm{Co}>4$ reflect an anoxic depositional environment, while the $\mathrm{V} / \mathrm{Cr}<2$ and $\mathrm{Ni} / \mathrm{Co}<4$ indicates an oxygen-rich depositional environment. The $\mathrm{V} / \mathrm{Cr}$ ratios of the analysed siliceous rocks range from 0.25 to 1.11 , which indicate that the depositional environment was oxygen-rich. The $\mathrm{Ni} / \mathrm{Co}$ ratios range from 0.96 to 9.87 , which indicate either an oxygen-rich depositional environment or a participation of mafic magmatism [64]. The presence of mafic magmatic activity could also contribute to the high $\mathrm{Cr}$ content in the siliceous rocks [66]. According to the $\mathrm{Sc} / \mathrm{Th}, \mathrm{U} / \mathrm{Th}$ and $\mathrm{Sr} / \mathrm{Ba}$ ratios, the $\mathrm{V} / \mathrm{Cr}$ and $\mathrm{Ni} / \mathrm{Co}$ ratios were probably influenced by the mafic magma rather than an aerobic environment. The associated magmatic activity should be related to the deep faults, such as FengxianFengzhen-Shanyang and Jiudianliang-Zhenan-Banyan faults $[1,32,34]$. Although there was no volcanic activity during the deposition process (Figure 11), the deep faults in the Fengtai area could also have provided favorable conditions for the mafic magmatism to affect hydrothermal convection.

(3) The analytical results of the rare earth element are shown in Table 4, and they indicated the following.

(a) The siliceous rocks originated from hydrothermal precipitation with slight influences from terrigenous materials. The $\Sigma$ REE values of the siliceous rocks range from $3.28 \mathrm{ppm}$ to $19.75 \mathrm{ppm}$ with an average of $9.83 \mathrm{ppm}$, which is consistent with that of siliceous rocks of hydrothermal sedimentary genesis [67]. Normalized by the PAAS [44] (Figures 14(a) and 14(b)), the siliceous rocks are divided into two groups. One group is tilted to the left with positive Eu anomalies and slightly weak Ce negative anomalies (Figure 14(a)), which is consistent with those of siliceous rocks with hydrothermal genesis. The other group is similar to that of the nonhydrothermal siliceous rock with negative $\mathrm{Eu}$ anomalies (Figure 14(b)) but does not support the nonhydrothermal genesis because of their inclination to the left. Because the ocean basin was insufficiently wide to prevent the terrestrial materials from influencing the original sedimentation process, the REE were only slightly affected by the terrestrial input with negative Eu anomalies (Figure 14(b)).

(b) The siliceous rocks were deposited in a marginal sea basin. The $(\mathrm{La} / \mathrm{Yb})_{N}$ ratios of the analysed siliceous rocks range from 0.10 to 1.52 , similarly to that of siliceous rock deposited in the basin of the marginal sea [68]. The $\delta \mathrm{Ce}$ values of siliceous rocks are typically 0.29 at the mid-ocean ridge, increasing gradually to 0.55 in the ocean basin, and range from 0.90 to 1.30 in the marginal sea next to the continent $[68,69]$. In this study, the present $\delta$ Ce values (from 0.80 to 0.92 ) are consistent with those of siliceous rocks deposited in the basin of a marginal sea [69]. The (La/Ce) ${ }_{N}$ ratios of siliceous rocks are typically 1 when deposited in marginal seas [53], which reflect the influences of terrigenous input [70]. The $(\mathrm{La} / \mathrm{Ce})_{N}$ ratios of the analysed samples range from 0.85 to 1.46 , which coincides with that of siliceous rock from marginal seas [53]. Also the $(\mathrm{La} / \mathrm{Lu})_{N}$ ratios (from 0.13 to 1.37 ) from the analysed siliceous rocks are approximately equal to that of siliceous rock deposited in marginal seas [67]. The hydrothermal diagenesis is represented by a Eupositive anomaly [71], whose $\delta$ Eu value generally decreases from 1.35 at the mid-ocean ridge to 1.02 at $75 \mathrm{~km}$ from the mid-ocean ridge $[53,67]$. The $\delta$ Eu values (from 0.28 to 1.84 ) of the analysed rocks did not match that of the siliceous rock formed at the mid-ocean ridge [69]. In the $\mathrm{Al}_{2} \mathrm{O}_{3} /\left(\mathrm{Al}_{2} \mathrm{O}_{3}\right.$ $\left.+\mathrm{Fe}_{2} \mathrm{O}_{3}\right)-(\mathrm{La} / \mathrm{Ce})_{N}$ discrimination diagram (Figure 15), the siliceous rocks plot in and next to the marginal sea field.

4.3. Raman Spectroscopy. Raman analysis was performed on the points $(A \rightarrow G)$ as shown in the microphotographs of Figures 16(a) and 16(b). The micrographs illustrate deformed quartz grains and carbonate minerals. The ellipses in Figures 16(a) and 16(b) represent the straining ellipse for granular quartz formation, which was analysed in parallel (A, B and E) and oblique crossing ( $C$ to $G$ ) directions in relation to the macroaxis. In the Raman analysis, the points were analysed in situ in certain directions (the direction in parallel with points $\mathrm{A}, \mathrm{B}$, and $\mathrm{E}$, while the oblique crossing direction including points C, D, E, F, and G). The spectral configurations for all the points are discussed elsewhere [15]. As shown in the spectrogram of the analysis points $(A \rightarrow G)$ (Figure 16(c)), the peaks are mainly caused by the $\mathrm{Si}-\mathrm{O}$ bond of quartz and the $\mathrm{CO}_{3}{ }^{2-}$ ion of carbonate mineral. In Figure 16(c), the peaks at $464 \mathrm{~cm}^{-1}$ exhibit $\alpha$-quartz according to previous work [72], and they were treated as a characteristic Raman shift. In addition, the peaks at $1112 \mathrm{~cm}^{-1}$ were also controlled by the $\mathrm{Si}-\mathrm{O}$ bond according to previous studies [73-75]. There are remarkable scattering peaks at $1091 \mathrm{~cm}^{-1}$, and they fall into the overlapping range of the antisymmetric vibration peak (from $1010 \mathrm{~cm}^{-1}$ to $1125 \mathrm{~cm}^{-1}$ ) of $\mathrm{Si}-\mathrm{O}$ and the $\mathrm{R}$ vibration peak of the $\mathrm{V}$-band for $\mathrm{CO}_{3}{ }^{2-}$ (from $1050 \mathrm{~cm}^{-1}$ 


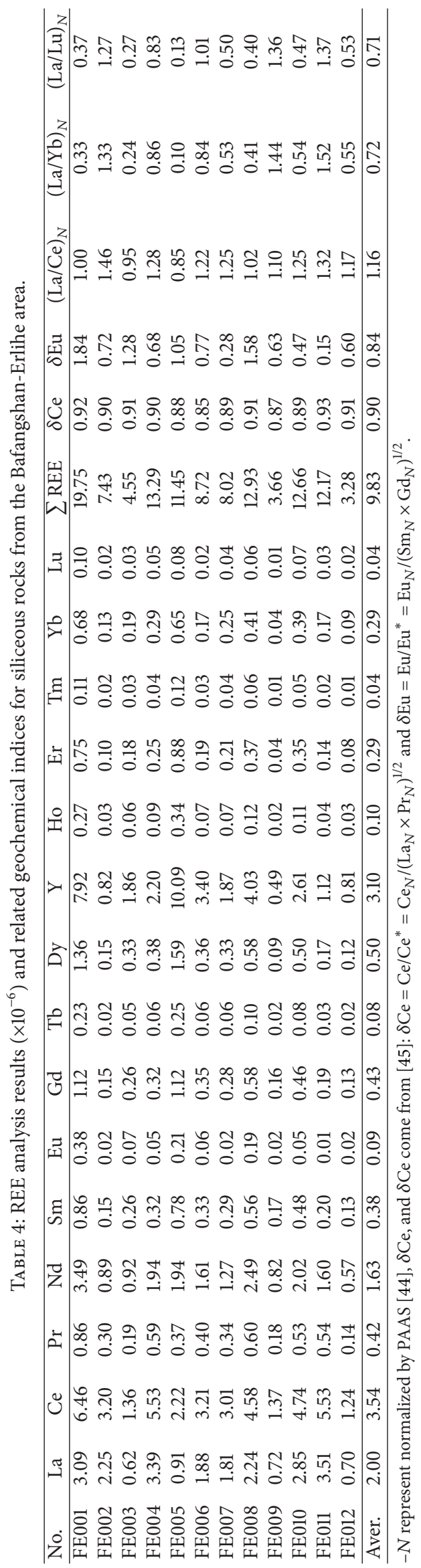




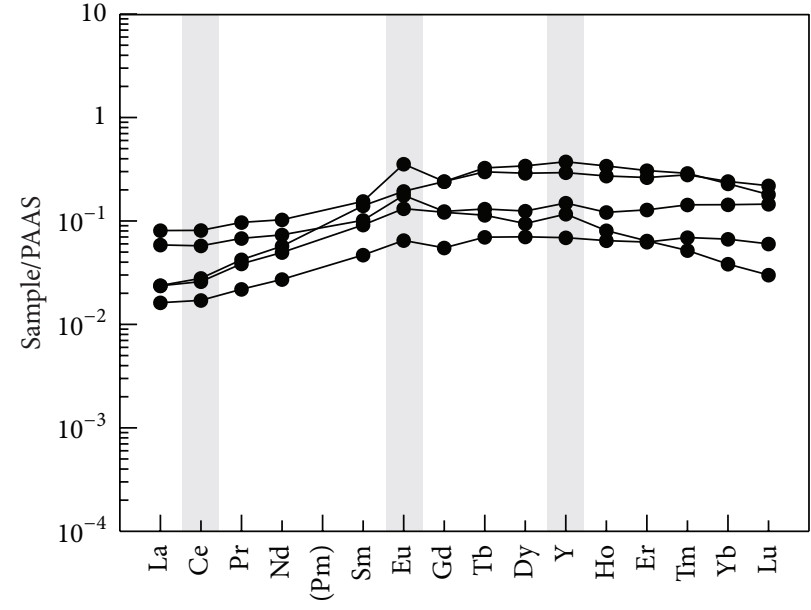

(a)

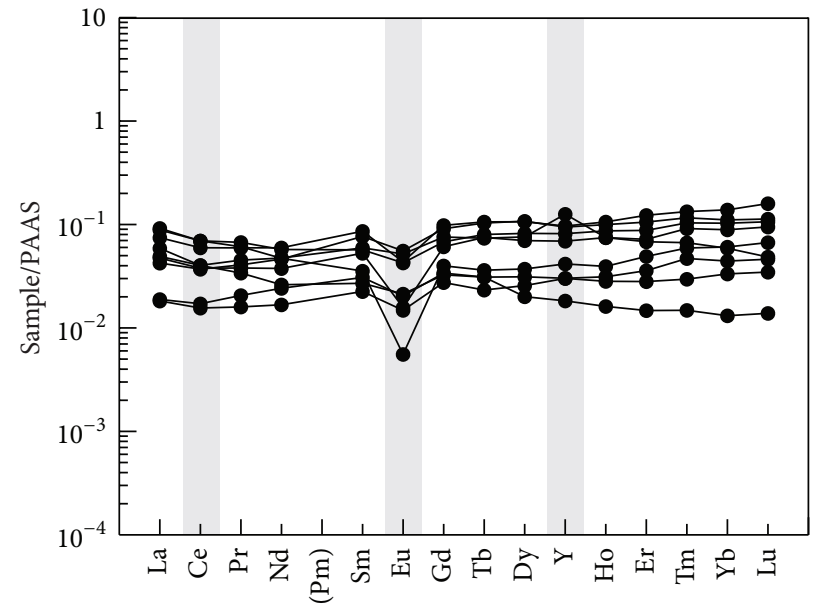

(b)

FIGURE 14: PAAS normalized REE pattern for siliceous rocks from the Bafangshan-Erlihe area.

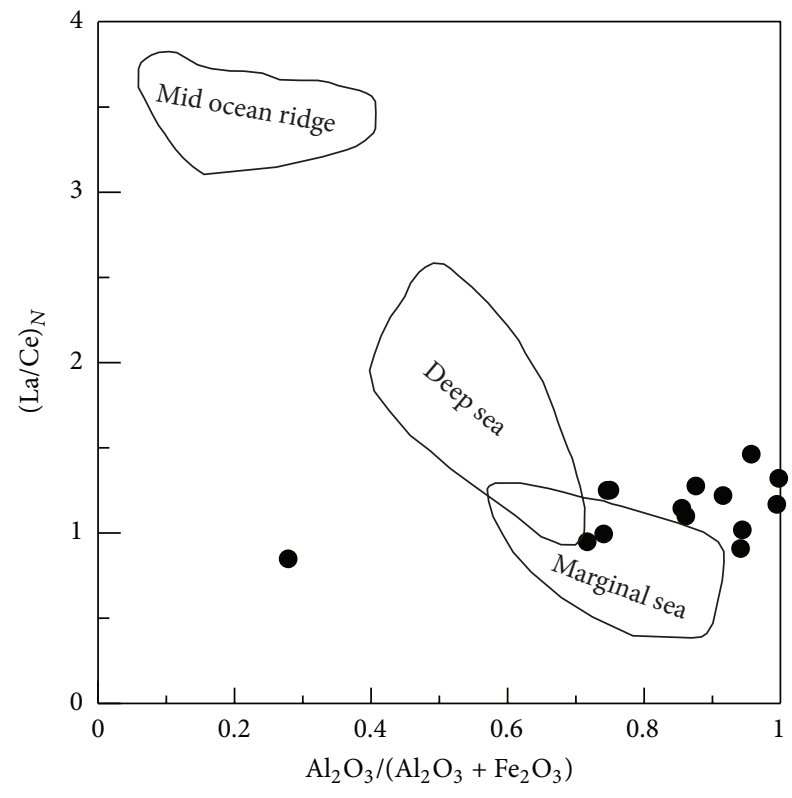

Figure 15: $\mathrm{Al}_{2} \mathrm{O}_{3} /\left(\mathrm{Al}_{2} \mathrm{O}_{3}+\mathrm{Fe}_{2} \mathrm{O}_{3}\right)-(\mathrm{La} / \mathrm{Ce})_{N}$ discrimination diagram for siliceous rock of the Bafangshan-Erlihe area (After[53]).

to $1090 \mathrm{~cm}^{-1}$ ). According to the Raman shift of calcite [76] and other carbonate minerals [77], the peaks at $1091 \mathrm{~cm}^{-1}$ should be attributed by the vibration of the $\mathrm{V}_{1}$-zone for the carbonate ions $\left(\mathrm{CO}_{3}{ }^{2-}\right)$. Additionally, the peaks at $1091 \mathrm{~cm}^{-1}$ are in accordance with the weak peak of the $\mathrm{V}_{4}$-zone at $722 \mathrm{~cm}^{-1}$ for carbonate ions, which are similar to peaks of ankerite. In the spectrograms, two weak peaks at $840 \mathrm{~cm}^{-1}$ and $1186 \mathrm{~cm}^{-1}$ could have originated from the metamorphic reaction between silica and carbonate, which exhibit symmetric and antisymmetric stretching vibration peaks for $\mathrm{Si}-$ $\mathrm{O}-\mathrm{R}$, and they are too weak to accurately estimate. The peaks at $1608 \mathrm{~cm}^{-1}$, which are attributed to the $\mathrm{C}-\mathrm{C}$ bond in benzene rings, came from the organic gum used in the experiment. The weak peaks at $280 \mathrm{~cm}^{-1}$ falling into the range of silicate mineral scattering peaks $[78,79]$ could have arisen from the metamorphic reaction between silica and carbonate. There are peaks on curves $\mathrm{C}$ to $\mathrm{G}$ for both quartz and carbonate minerals in the spectrogram (Figure 16(c)). This phenomenon demonstrates the carbonate composition infiltrating the quartz through the discontinuous portion caused by stress during orogeny. In addition, the degree of infiltration increases from the edge to the centre of the quartz grain [15].

The crystallinity and degree of order for the quartz grains increased during recrystallization $[80,81]$, which could be denoted by the Gaussian best-fit to the characteristic Raman peaks at $464 \mathrm{~cm}^{-1}$ for the quartz grains [82, 83]. Figure 17 suggests a Gaussian fitting for the characteristic Raman shifts at $464 \mathrm{~cm}^{-1}$ from points $C$ to $G$. In the Gaussian fitting, the full width at half maximum (FWHM) values ascends from the centre outwards in concert with the crystallinity and degree of order but abruptly descends at the edge closest to the carbonate periphery. According to previous work [80], the crystallinity increases during the upper evolution of the quartz minerals from the centre to the quartz edge. Based on this finding, the FWHM values ascend from the centre outwards, meaning that the decline in crystallinity might be a result of the autorecrystallisation of quartz. The abrupt increase in crystallinity exists at the edge of quartz, and this should be contributed by the fluids during orogeny.

According to Figure 18, the Gaussian fitting of characteristic Raman shifts at $464 \mathrm{~cm}^{-1}$ indicates discrepancies in a direction parallel to the macroaxis. In Figure 16(b), the points of $\mathrm{A}, \mathrm{B}$, and $\mathrm{E}$ lay parallel to the macroaxis of the quartz grains, and their FWHM values also showed some slight discrepancies. According to the discrepancy in the FWHM value, there are slight deviations of crystallinity parallel to the macroaxis of the straining ellipse. These deviations should 


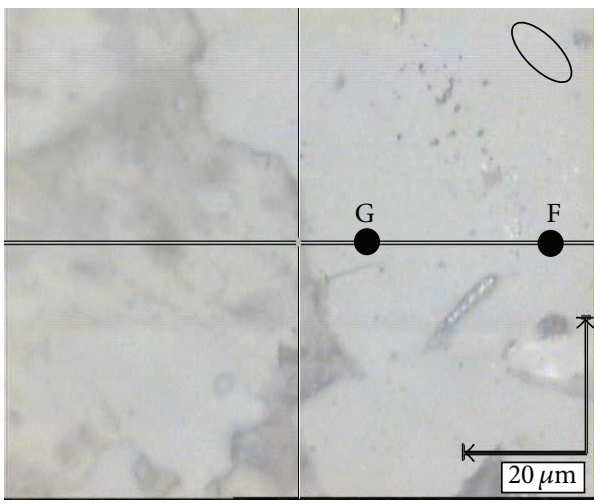

(a)

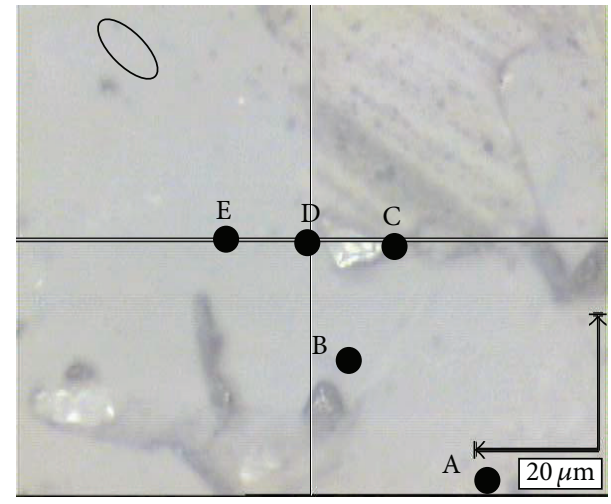

(b)

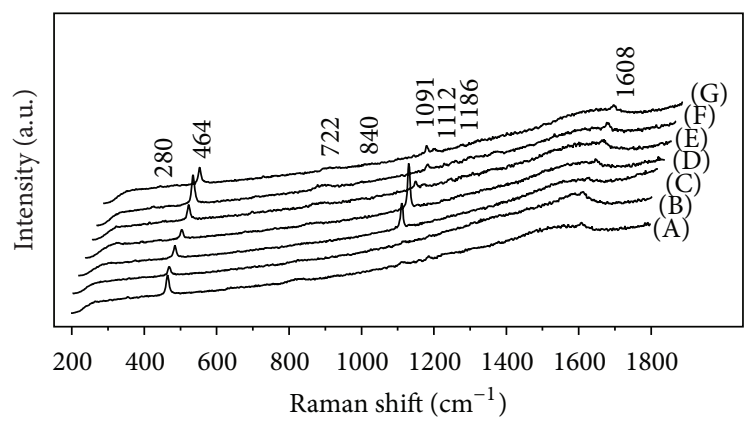

(c)

FIGURE 16: Points of Raman analysis for siliceous rocks of Bafangshan-Erlihe area. Microphotographs in Figures 16(a) and 16(b) under parallel nicols.

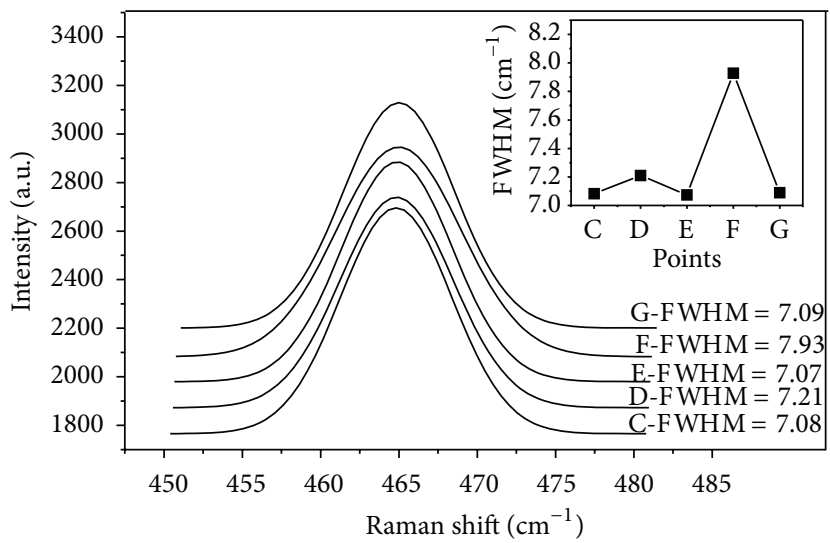

Figure 17: Gaussian fitting to characteristic Raman shift of quartz in siliceous rock from Bafangshan-Erlihe area.

relate to external factors during orogeny, such as the stress field and fluid effects. Therefore, there are overall geochemical stabilities for the siliceous rocks with slight changes in the crystallinity.

4.4. XRD. X-ray powder diffraction (Figures $19(\mathrm{a})$ and 19 (b)) of the pure siliceous rock indicates quartz as the major mineral. Trace impurities, such as carbonate and clay minerals, are concealed in the analytical results. There are two

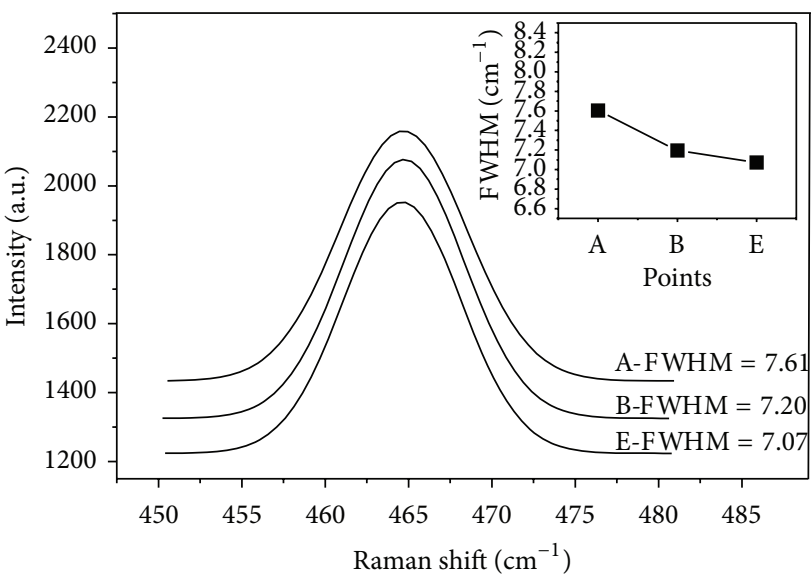

FIgURE 18: Gaussian fitting to a characteristic Raman shift for siliceous rock of the Bafangshan-Erlihe area.

types of quartz in the siliceous rocks (Figure 19(b)). One (Qtz) is hexagonal, with space group P3 21 (152), the crystal cell parameters of which were $a=b=4.913 \AA, c=$ $5.405 \AA$, and $Z=3$, that is, identical to those of standard $\alpha$-quartz. The other (Qtzs) is rhombohedral, having shorter crystal cell parameters and is similar to a quartz with space group P312(149), as noted elsewhere [15, 18]. The crystal cell parameters were $a=b=4.903 \AA, c=5.393 \AA$, and $Z=3$. 


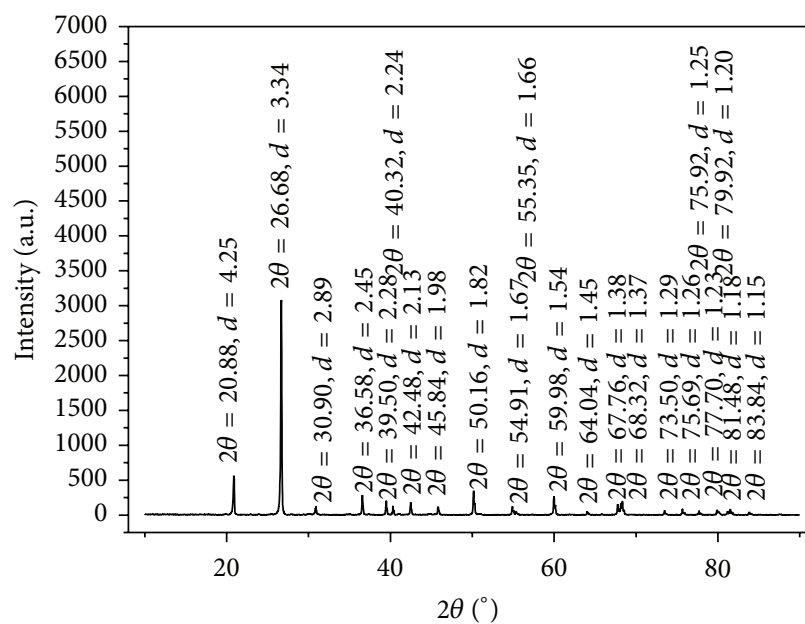

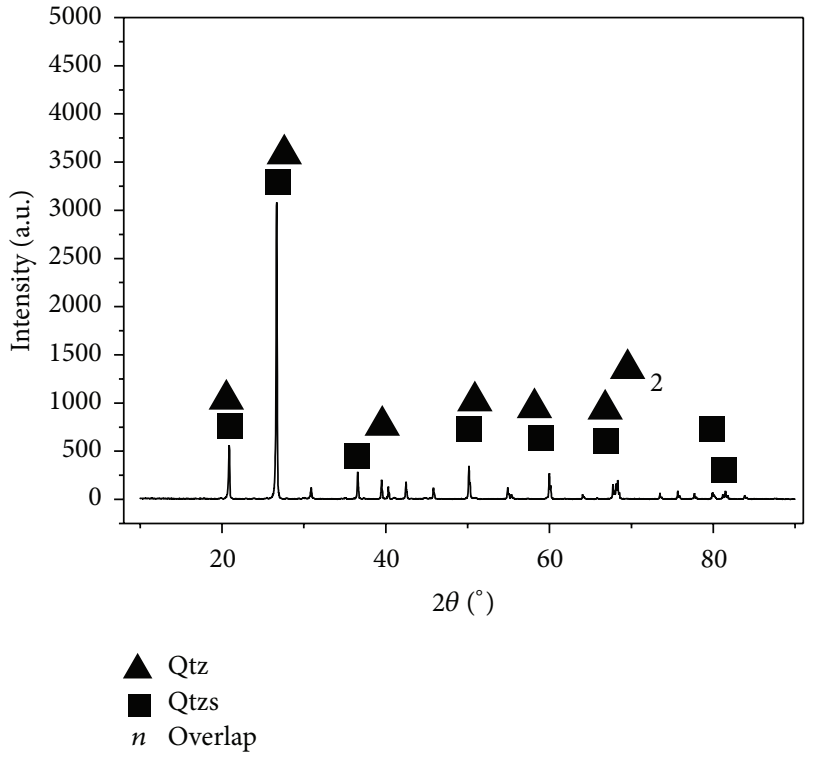

(b)

FIGURE 19: XRD diagram for siliceous rock of the Bafangshan-Erlihe area.

The crystal cell parameters should be similar under uniform crystallizing environments and evolutionary processes. According to previous work, changes in crystal cell parameters can be effected by four factors as follows: temperature [84], stress [85], transformation into different crystal forms $[86,87]$, and isomorphous substitution [88]. In this study, crystal cell parameter shortening was possibly controlled by the primary factors of temperature and stress during the evolution of the $\mathrm{COB}$, while the other factors could only have lengthened the cell parameters.

4.5. SEM. In the Electron Back Scatter Diffraction (EBSD) images of mineralized siliceous rock (Figure 20(a)), there are three principal phases, namely, quartz, carbonate mineral (calcite or dolomite), and metal sulphides (such as galena, sphalerite, or pyrite). The quartz particles of low crystallinity occupy the main body of the siliceous rocks, while the carbonates and metal sulphides are scattered with disseminated distribution (Figures 20(a) and 20(b)). The carbonate particles (Figure 20(c)) and pyrite (Figure 20(d)) sometimes show idiomorphic crystals, which indicates that they were originated from primary sedimentation. Metal sulphides were probably deposited at the end of high-temperature sedimentation. Although the siliceous rocks were involved in subsequent orogeny (Figure 20(b)), the metal sulphides are mainly disseminated without fracture-filling distribution (Figures 20(a) to 20(c)). Although the distribution of metal sulphides retained the primary characteristics of sedimentary genesis, a few metal sulphides, with fracture-filling distribution, might have been affected by the orogeny. These types of metal sulphides are distributed near the weaker part of the siliceous rocks, such as the fissures of the quartz and the carbonate mineral (Figure 20(b)). Therefore, it is suggested that the silica and metal sulphides were simultaneously deposited, and the metal sulphides are also precipitation products of hydrothermal sedimentation. The dominant minerals show low automorphism, which is attributed by their rapid deposition with insufficient time to crystallize and grow.

\section{Discussion}

5.1. Mineralogical and Geochemical Evolution. The studied siliceous rocks underwent mineralogical adjustments with maintenance of geochemical stability. In nature, elevated temperatures and pressures result in deformation of different rocks [89]. The quartz grains show plastic deformation under the strain rate of $0 \sim 10^{-13} / \mathrm{s}$ and temperature of $300^{\circ} \mathrm{C}$ [90]. Microscopically, we observed recrystallized quartz with larger grain size in the siliceous rocks without mineralization, which exhibits directional arrangement to some extent. In the Raman analysis, the FWHM values of characteristic peaks (next to $464 \mathrm{~cm}^{-1}$ ) showed inhomogeneity in the degree of crystallinity in diverse directions. This indicated that the crystallinity is different in the microareas of an individual quartz grain. As shown in the XRD analysis, the recrystallization of quartz was witnessed by the shortening cell parameter of quartz grains. Thus, the recrystallization of quartz is evidenced by both XRD analysis and Raman in situ analysis. Although the quartz underwent clear recrystallisation, under the influences of temperature and stress during the orogeny (according to [91]), these changes could only account for fabric changes. It is demonstrated that, the degrees of order in silica minerals may increase without exterior influence [76], and that geochemical stability of the total rocks can be still maintained with increasing crystallinity degree [80]. For the studied siliceous rocks, there is a high consistency to the hydrothermal genesis model, based on the geochemical 


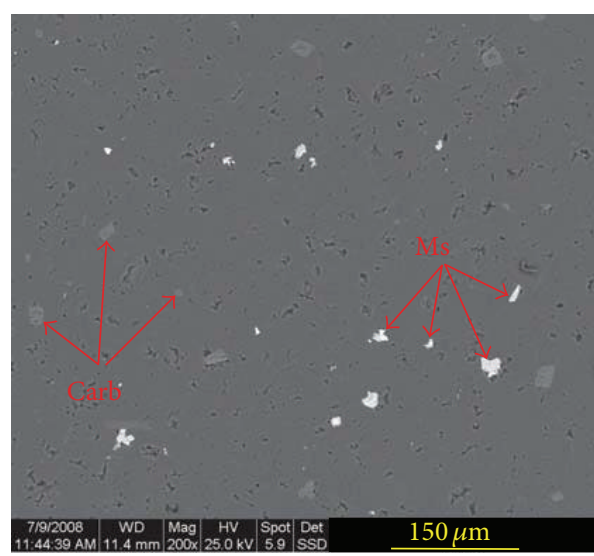

(a)

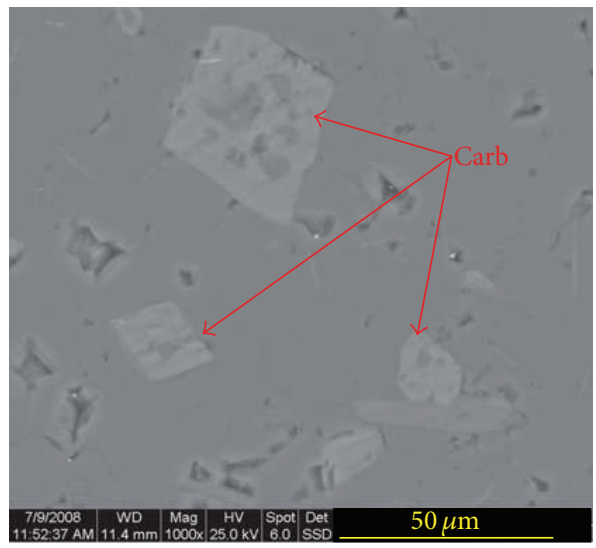

(c)

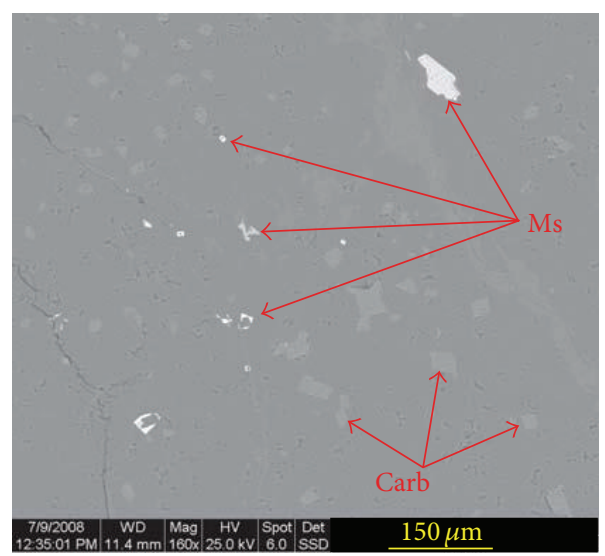

(b)

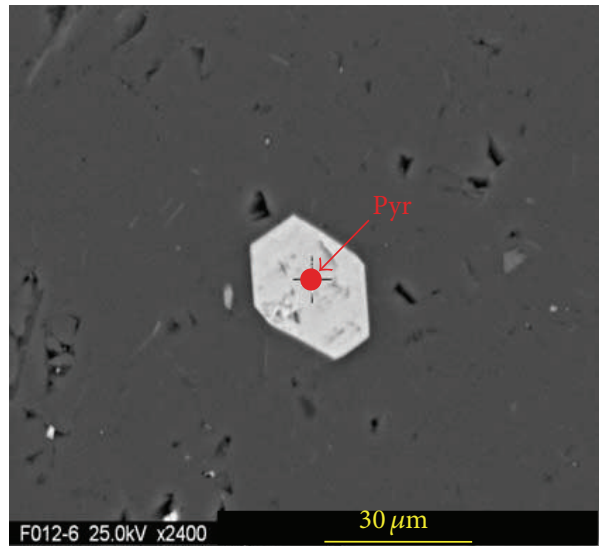

(d)

FIGURE 20: EBSD images for siliceous rock of the Bafangshan-Erlihe area (Carb: carbonate mineral, Ms: metal sulphide, Pyr: pyrite).

and microfabric characteristics, as well as the geochemical discrimination diagrams of formation environment. Our study suggests that there is high stability for the original geochemical characteristics of the siliceous rocks and that these were maintained without any change in the total rocks.

5.2. Genesis of Siliceous Rocks. It is suggested here that the siliceous rocks in Central Orogenic Belt, China, and the Bafangshan-Erlihe ore districts are hydrothermal precipitates. The siliceous rocks, in addition to clay rock, clastic and carbonate rocks, are the most widely distributed sedimentary rock in this orogenic belt $[3,19,92]$, and their formation is previously attributed to biogenesis [93], metasomatosis (or silicification) $[94,95]$ or chemical deposition $[49,96]$. On a large scale, the sedimentary siliceous rocks could hardly be deposited in the marine environment with only terrigenous silica contribution. The high purity and large quantity of silica consumed for the deposition of the siliceous rocks, could not be completely caused by any terrigenous and nonhydrothermal deposition system [97-99]. This supports the idea that the massive sedimentary siliceous rocks were originated from hydrothermal precipitation according to [100]. The pure siliceous rocks could only have been deposited if the silica was present at a higher concentration in solution than other chemical components, resulting in high deposition rates of silica and favouring deposition of siliceous rocks instead of other sediments (carbonate, clay and metallic minerals) [16]. In this way, high rates of pure silica accumulation would develop without interference from other sediments. Terrigenous silica is difficult to precipitate during the migration process because of its very low solubility [101]. Even if there was rapid precipitation of silica at a low concentration, it was still difficult to deposit the siliceous sediments at a large scale with high purity after long-term and sustained transportation or other extreme conditions [99]. Furthermore, the $\mathrm{SiO}_{2}$ was extremely low in the normal seawater, and this could contribute to a low deposition rate $[16,97]$, while the quartz grains would grow better and bigger due to the adequate crystallizing time. The quartz grains in the siliceous rocks from the Bafangshan-Erlihe area, seem to have insufficient crystallization and growth, which is in contrast to quartz originated from the deposition of terrigenous silica with a low deposition rate. The microphotographs and EBSD indicate the silica minerals exhibited low-degree crystallinity, which was in accordance with the typical siliceous rocks of hydrothermal genesis [36]. During the hydrothermal precipitation, the quartz grains could not fully crystallise at high deposition rates of silica, and they 
therefore showed close-packed structures as a consequence of their rapid accumulation of the silica.

The ore-bearing siliceous rocks of Bafangshan-Erlihe area were considered to be of hydrothermal genesis also on the base of their geochemical characteristics. Some geochemical indices, such as the average $\mathrm{Ba}$ (196.64 ppm), $\Sigma$ REE values $(9.83 \mathrm{ppm})$ and ratios of $\mathrm{Al} /(\mathrm{Al}+\mathrm{Fe}+\mathrm{Mn})(0.36)$, $\mathrm{Fe} / \mathrm{Ti}$ (335.44), $(\mathrm{Fe}+\mathrm{Mn}) / \mathrm{Ti}$ (347.80) and $\mathrm{Ba} / \mathrm{Sr}$ (8.07), all suggest their genesis through hydrothermal deposition. In the geochemical discrimination diagrams, the siliceous rocks fall into the category of hydrothermal genesis and this is in agreement with their REE patterns. Therefore, it is considered that the siliceous rocks were deposited from a convective hydrothermal system within a crustal extensional setting. On the other hand, the MgO, $\Sigma \mathrm{REE}, \mathrm{Si} / \mathrm{Al}$ and $\mathrm{U} / \mathrm{Th}$ of several samples disagree with the hydrothermal characteristics, and indicate that the sedimentary systems were affected by the input of nonhydrothermal materials (e.g., terrigenous and biological substances). The contribution of terrigenous materials is strongly supported by the presence of detrital zircons in the siliceous rocks [12]. Microorganisms, carrying terrigenous substances, were also involved in the precipitation process of the hydrothermal silica, and resulted in the observed fluctuations from normal hydrothermal characteristics. Therefore, the ore-bearing siliceous rocks in the Bafangshan-Erlihe area were originated from hydrothermal precipitation with some additional influence from terrigenous and biological sources.

5.3. Depositional Environment of Siliceous Rocks. The siliceous rocks of the Bafangshan-Erlihe area were deposited in a limited basin of a marginal sea. They were conformably deposited over the Middle Devonian marine limestone, which indicates their deposition in a marine environment with deep to shallower water. The geochemical indices, such as the $\mathrm{Al} /(\mathrm{Al}+\mathrm{Fe}+\mathrm{Mn}), \mathrm{Al}_{2} \mathrm{O}_{3} /\left(\mathrm{Al}_{2} \mathrm{O}_{3}+\mathrm{Fe}_{2} \mathrm{O}_{3}\right)$, $\mathrm{Sc} / \mathrm{Th},(\mathrm{La} / \mathrm{Yb})_{N},(\mathrm{La} / \mathrm{Ce})_{N}$, and $(\mathrm{La} / \mathrm{Lu})_{N}$, demonstrate that the siliceous rocks were deposited in a marginal sea basin, in coincidance with the geochemical discrimination diagrams. The $\mathrm{K}_{2} \mathrm{O} / \mathrm{Na}_{2} \mathrm{O}, \mathrm{SiO}_{2} /\left(\mathrm{K}_{2} \mathrm{O}+\mathrm{Na}_{2} \mathrm{O}\right)$, and $\mathrm{SiO}_{2} / \mathrm{Al}_{2} \mathrm{O}_{3}$ ratios are significantly higher than those of volcanism-related siliceous rocks and indicate that there was no obvious volcanic activity during the formation process. However, magmatic bodies emplaced at depth and under extensional conditions, may have caused hydrothermal convection through deep faults, by providing heat in the system. The associated magma was mafic according to the $\mathrm{V} / \mathrm{Cr}$ and $\mathrm{Ni} / \mathrm{Co}$ ratios. The $\mathrm{V} /(\mathrm{V}+\mathrm{Ni})$ ratios indicate that the sedimentation conditions were slighlty oxidative, which should reflect intermingling with terrigenous substances. In previous studies [102-104], it has been suggested that the ocean basin of the COB was width-limited and narrow, which strongly supports the input of terrigenous materials during the hydrothermal precipitation. In agreement with the previous studies $[102,104]$, a deposition of siliceous rocks in relatively shallow seawater, is also supported by the fact that these rocks are located on top of carbonate rocks of Gudaoling Formation. According to the geochemical characteristics
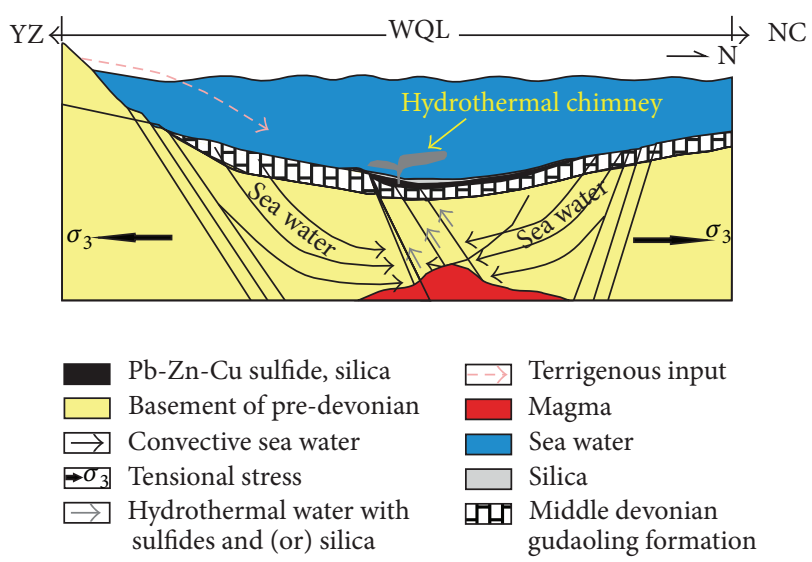

FIGURE 21: Hydrothermal precipitation model of the BafangshanErlihe area (YZ: Yangtze block, WQL: western Qinling block, NC: North China block).

and the presence of detrital zircons in the siliceous rocks [12], terrigenous materials participated in the sedimentation process of hydrothermal silica. The hydrothermal activity attracted many elements with an affinity to silicon [105], and this attraction might induce the biological production within a large population of organisms [106, 107]. These organisms can carry nonhydrothermal substances because of their long-distance activities and needs for special elements, such as phosphorus [108]. Under this situation, the organisms which were involved in the sedimentation process exhibit also terrigenous characteristics, and their dead bodies and catabolites have been deposited together with hydrothermal sediments according to [106]. Both terrigenous material and biological activities partly contributed to the formation of the siliceous rocks, as may be expected to be the case in a geological setting of a limited ocean basin [102-104]. By expanding previous studies that the $\mathrm{COB}$ was neritic facies during the Middle Permian [28], this work suggests that the whole COB was a limited ocean basin with deep to shallower seawater neritic facies since the Middle Paleozoic.

5.4. Hydrothermal Model. The hydrothermal sedimentation at the Bafangshan-Erlihe area was controlled by the extensional tectonic setting during Devonian times, and underwent different stages with diverse contribution of hydrothermal fluids (Figure 21). In general, the entire process of hydrothermal activity experienced an evolution from hightemperature precipitation of sulphide to low-temperature precipitation of silica (see below). Within the broad spectrum of exhalative-inhalative deposits, the two end-members, for example, sedimentary exhalative deposit (SEDEX) $[109,110]$ and volcanogenic massive sulphide deposit (VMS) [111, 112] are diverse in respect to their country rocks and orehosting rocks, as well as their fluid origin and characteristics. According to published literatures [113, 114], sulphidebearing hydrothermal solution exhaled at the initial stages of hydrothermal activity under high temperatures, followed by exhalation of the silica-enriched hydrothermal waters, at a lower temperature with low dissolving capacity. Therefore, 
the silica rich hydrothermal water and sulphide-bearing hydrothermal solutions belonged to part of an evolving hydrothermal system. Previous studies delineate two models for the formation of SEDEX deposits: one considers tectonic activity and the geothermal gradient during sediment compaction (diagenesis) as the key factors for ore element migration in a highly saline formational brine, while the other considers hydrothermal fluids generated from seawater convection driven by a magma chamber intruding into sediments, and synsedimentary fault activity, as key factors in mineralization [115-118]. According to the $\mathrm{V} / \mathrm{Cr}$ and $\mathrm{Ni} / \mathrm{Co}$ ratios and discrimination diagrams, the siliceous rocks, as well as the metal sulphides, of the Bafangshan-Erlihe ore deposit were originated from the convection of hydrothermal water. Similarly, other trace elements could have been introduced from the hydrothermal water to form ore deposits (according to $[8,9]$ ). In the Bafangshan-Erlihe region, the sea basin was formed as a result of the extensional tectonics (e.g. rifting). Normal basin-bounding faults related to the extensional tectonic setting near the suture zones could facilitate emplacement of magmas as proposed by [16]. The extensional tectonics could also provide a favorite environment to drive the hydrothermal convection [43]. The hydrothermal water moved upward along the syn-sedimentary fractures in the Bafangshan-Erlihe area, precipitating hydrothermal sediments on the seafloor within the basin after mixing with cold seawater.

During the final stages of magmatic activity, high temperature hydrothermal water with high potential solubility and dissolution of silica, were analogous to those precipitating modern metal sulphide chimneys (black smokers) [119]. In the ores from the Bafangshan-Erlihe $\mathrm{Cu}-\mathrm{Pb}-\mathrm{Zn}$ ore deposit [120], the isotopic ${ }^{206} \mathrm{~Pb} /{ }^{204} \mathrm{~Pb}$ (from 18.02 to 18.15), ${ }^{207} \mathrm{~Pb} /{ }^{204} \mathrm{~Pb}$ (from 15.56 to 15.81 ), and ${ }^{208} \mathrm{~Pb} /{ }^{204} \mathrm{~Pb}$ (from 37.99 to 38.66) are similar to those of modern oceanic sediments, which suggest their sources from both the upper crust and mantle. In addition, the $\delta^{34} S$ values of sulphides range from $6.03 \%$ to $11.86 \%$ and indicate a genesis of sulphides by sulphate reduction from sea water. These isotope geochemical characteristics strongly support the hypothesis that the ores were deposited in a marine context during hydrothermal convection, as also evidenced by the distribution of metal sulphides in the ore-bearing siliceous rocks. Furthermore, the orebodies were located at the bottom of the siliceous rocks, which suggests that their precipitation predates that of silica, and took place at the onset of the hydrothermal activity at higher temperatures.

A decrease in silica solubility at lower temperatures resulted in precipitation of pure silica. Since the solubility of silica is higher than that of metal sulphides at low temperatures [113], pure silica could only deposit at a relative low temperature. At this time, the hydrothermal precipitation process was akin to that of colder silica-enriched hydrothermal water (white chimney) [114]. Previous studies demonstrated that $\mathrm{SiO}_{2}$ solubility in the seawater at $150^{\circ} \mathrm{C}$ was $600 \mathrm{ppm}$ [100], while it was ten times higher at $200^{\circ} \mathrm{C}$ than $50^{\circ} \mathrm{C}$ [121]. Therefore, the hydrothermal fluid was capable to dissolve silica and other trace elements from the sedimentary strata and became silica-enriched. By discharging on the seafloor, the silica-rich hydrothermal fluid mixed with the cold seawater, and the temperature dropped to cause silica precipitation as a consequence of $\mathrm{SiO}_{2}$ oversaturation [122].

The hydrothermal- and tectonic activities were contemporaneous at the Bafangshan-Erlihe area. Following the hydrothermal activity, deposition of the clastic rock formation (later metamorphosed to phyllites) and limestones took place. The hydrothermal system contributed to the precipitations of metal sulphide and siliceous rocks with geochemical characteristics of hydrothermal genesis. Terrigenous material, magmatism, and biological activity resulted in some geochemical deviation compared with classic hydrothermal sediments, but without changing the hydrothermal characteristics of the whole sedimentary formation.

\section{Conclusions}

(1) Siliceous rocks of the Bafangshan-Erlihe ore deposit were originated from hydrothermal precipitation. In microphotographs and EBSD images, the low degree of crystallinity and close-packed quartz grain texture indicates their hydrothermal genesis. The $\mathrm{SiO}_{2}$ content varies from $71.08 \%$ to $95.30 \%$ with an average of $84.10 \%$. The hydrothermal genesis of the siliceous rocks is witnessed by the $\mathrm{Al} /(\mathrm{Al}+\mathrm{Fe}+\mathrm{Mn})$ ratio ranging from 0.03 to $0.58,(\mathrm{Fe}+\mathrm{Mn}) /$ Ti ranging from 15.59 to 1031.45, Ba ranging from $42.45 \mathrm{ppm}$ to $503.00 \mathrm{ppm}$ and $\Sigma \mathrm{REE}$ values ranging from $3.28 \mathrm{ppm}$ to $19.75 \mathrm{ppm}$.

(2) Siliceous rocks of the Bafangshan-Erlihe region were deposited in marginal sea basin according to the geochemical discrimination diagrams. Additional geochemical data indicating that the deposition environment was a basin of a marginal sea, are $\mathrm{Al} /(\mathrm{Al}+\mathrm{Fe}+\mathrm{Mn})$ ratios ranging from 0.03 to $0.58, \mathrm{Sc} / \mathrm{Th}$ ratios ranging from 0.10 to $13.85,(\mathrm{La} / \mathrm{Yb})_{N}$ ratios ranging from 0.10 to $1.52,(\mathrm{La} / \mathrm{Ce})_{N}$ ratios ranging from 0.85 to 1.46 and $(\mathrm{La} / \mathrm{Lu})_{N}$ ratios ranging from 0.13 to 1.37.

(3) The siliceous rocks in the Central Orogenic Belt, China, had a periodic distribution in geological history and were mainly developed under periods of continental rifting. There were three depositing phases for the marine siliceous rocks with broader distribution from Mesoproterozoic to Jurassic. The periods for the positive peaks of distribution number were Mesoproterozoic, Cambrian Ordovician, and Carboniferous $\sim$ Permian. During the Caledonian (from Simian to Late Silurian) and Hercynian (from Devonian to Late Permian) periods, the siliceous rocks are widely distributed as a result of extentional tectonics, favoring their formation. The Jinning, Caledonian, Hercynian, Indosinian, and Yanshanian orogenies contributed to compressional setting and resulted in a sudden decrease in distribution numbers of siliceous rock.

(4) Hydrothermal fluids ascended along syn-sedimentary faults in the Bafangshan-Erlihe area, discharging hydrothermal sediments on the seafloor after mixing with cold seawater. The hydrothermal activity of the Bafangshan-Erlihe ore deposit evolved from initial high-temperature towards late low-temperature stages. High-temperatured hydrothermal sediments include metal sulphides and silica, while lowtemperature sediments were mainly composed of silica. 
Apart from the hydrothermal sedimentation, terrigenous input, magmatism, and biological activity partly contributed to some geochemical indicators deviating from typical hydrothermal characteristics.

\section{Conflict of Interests}

The authors declare that there is no conflict of interests regarding the publication of this paper.

\section{Acknowledgments}

This study was financially supported by the Natural Science Foundation of China (Grant 41303025), the 973 Program of China (Grant 2012CB406601), the Natural Science Foundation of China (Grants 41373025 and 41273040) and the Subject and Special Fund of the Ministry of Science and Technology of the State Key Laboratory of Geological Processes and Mineral Resources (Grant GPMR200804). Professor G. Racki, Y. Watanabe, and Professor M. Santosh are greatly acknowledged for their helpful and constructive comments on the manuscript. Professor G. Racki is especially thanked for the editorial handling of the paper.

\section{References}

[1] W. Fang, F. Liu, R. Hu, and Z. Huang, "The characteristics and diagenetic-metalogenic pattern for cherts and siliceous ferrodolomitites from Fengtai apart-pull basin, Qinling orogen," Acta Petrologica Sinica, vol. 16, no. 4, pp. 700-710, 2000.

[2] S. Feng, H. Zhou, C. Yan, Y. Peng, X. Yuan, and J. He, "Geochemical characteristics of hydrothermal cherts of erlangping group in east qinling and their geologic significance," Acta Sedmentological Sinica, vol. 25, no. 4, pp. 564-573, 2007.

[3] C. Zhang, D. Zhou, G. Lu, J. Wang, and R. Wang, "Geochemical characteristics and sedimentary environments of cherts from Kumishi ophiolitic mélange in southern Tianshan," Acta Petrologica Sinica, vol. 22, no. 1, pp. 57-64, 2006.

[4] H. Li, Y. Zhou, Z. Yang et al., "Geochemical characteristics and their geological implications of cherts from Bafangshan-Erlihe area in Western Qinling Orogen," Acta Petrologica Sinica, vol. 25, no. 11, pp. 3094-3102, 2009.

[5] G. Tu, Geochemistry of the Stratabound Ore Deposits in China, vol. 1, Science, Beijing, China, 1984.

[6] J. Mao, Z. Zhang, J. Yang, G. Zuo, and D. Ye, The Metallogenic Series and Prospecting Assessment of Copper, Gold, Iron and Tungsten Polymetallic ore Deposits in the West Sector of the Northern Qilian Mountains, Geological Publishing House, Beijing, China, 2003.

[7] D. Fan, T. Zhang, and J. Ye, Chinese Black Rock Series and Relevant Ore Deposits, Science Publishing House, Beijing, China, 2004.

[8] N. Tribovillard, T. J. Algeo, T. Lyons, and A. Riboulleau, "Trace metals as paleoredox and paleoproductivity proxies: an update," Chemical Geology, vol. 232, no. 1-2, pp. 12-32, 2006.

[9] S. E. Calvert and T. F. Pedersen, "Chapter fourteen: elemental proxies for palaeoclimatic and palaeoceanographic variability in marine sediments: interpretation and application," Developments in Marine Geology, vol. 1, pp. 567-644, 2007.
[10] S. Qi, "Devonian hydrothermal sedimentary Pb-Zn deposits in Qinling mountains," Journal of Chang'an University, vol. 15, no. 1, pp. 27-34, 1993.

[11] S. Qi and Y. Li, "The metallogenic series related to exhalative sedimentation in devonian metallogenic belt, south Qinling," Journal of Xian College of Geology, vol. 19, no. 3, pp. 19-26, 1997.

[12] R. T. Wang, F. L. Li, E. H. Chen, J. Z. Dai, C. A. Wang, and X. F. $\mathrm{Xu}$, "Geochemical characteristics and prospecting prediction of the Bafangshan-Erlihe large lead-zinc ore deposit, Feng County, Shaanxi Province, China," Acta Petrologica Sinica, vol. 27, no. 3, pp. 779-793, 2011.

[13] C. Xue, J. Ji, L. Zhang, D. Lu, H. Liu, and Q. Li, “The Jingtieshan submarine exhalative-sedimentary iron-copper deposit in North Qilian mountain," Mineral Deposits, vol. 16, no. 1, pp. 21-30, 1997.

[14] F. Zhang, "The recognition and exploration significance of exhalites related to $\mathrm{Pb}-\mathrm{Zn}$ mineralizations in devonian formations in qinling mountains," Geology and Prospecting, vol. 25, no. 5, pp. 11-18, 1989.

[15] H. Li, Z. Yang, Y. Zhou et al., "Microfabric characteristics of cherts of Bafangshan-Erlihe $\mathrm{Pb}-\mathrm{Zn}$ ore field in the western Qinling orogen," Earth Science, vol. 34, no. 2, pp. 299-306, 2009.

[16] H. Li, M. Zhai, L. Zhang et al., "he distribution and composition characteristics of siliceous rocks from Qinzhou Bay-Hangzhou Bay Joint Belt, South China: constraint on the tectonic evolution of plates in South China," The Scientific World Journal, vol. 2013, Article ID 949603, 25 pages, 2013.

[17] C. Xue, Devonian Hydrothermal Sedimentation in Qinling, Xian Map Press, Xi’an, China, 1997.

[18] H. Li, Y. Zhou, Z. Yang et al., "Diagenesis and metallogenesis evolution of chert in west Qinling orogenic belt: a case from Bafangshan-Erlihe $\mathrm{Pb}-\mathrm{Zn}$ ore deposit," Journal of Jilin University (Earth Science Edition), vol. 41, no. 3, pp. 715-723, 2011.

[19] H. Li, Y. Zhou, Z. Yang et al., "A study of micro-area compositional characteristics and the evolution of cherts from Bafangshan-Erlihe $\mathrm{Pb}-\mathrm{Zn}$ ore deposit in Western Qinling Orogen," Earth Science Frontiers, vol. 17, no. 4, pp. 290-298, 2010.

[20] Y. Chen, H. Chen, Y. Liu et al., "Progress and records in the study of endogenetic mineralization during collisional orogenesis," Chinese Science Bulletin, vol. 45, no. 1, pp. 1-10, 2000.

[21] S. Vearncombe, M. E. Barley, D. I. Groves, N. J. McNaughton, E. J. Mikucki, and J. R. Veancombe, "3.26 Ga black smokertype mineralization in the Strelley Belt, Pilbara Craton, Western Australia," Journal of the Geological Society, vol. 152, no. 4, pp. 587-590, 1995.

[22] H. Ohmoto and M. B. Goldhaber, "Sulfur and carbon isotope," in Geochemistry of Hydrothermal Ore Deposits, H. L. Barnes, Ed., pp. 517-612, John Wiley \& Sons, New York, NY, USA, 3rd edition, 1997.

[23] G. Zhang, B. Zhang, and X. Yuan, Qinling Orogen and Continental Dynamics, Science, Beijing, China, 2001.

[24] G. Zhang, Y. Dong, and A. Yao, "The crustal compositions, structures and tectonic evolution of the Qinling orogenic belt," Geology of Shanxi, vol. 15, no. 2, pp. 1-14, 1997.

[25] R. Zeng, S. Liu, C. Xue, and J. Gong, "Episodic-fluid process and effect of diagenesis and mineralization in evolution of paleozoic basins in South Qinling," Journal of Earth Sciences and Environment, vol. 29, no. 3, pp. 234-239, 2007.

[26] W. Yang, "Opening and closing history in east Qinling area," Earth Science, vol. 12, no. 5, pp. 487-493, 1987. 
[27] J. Liu, M. Zheng, J. Liu, Y. Zhou, X. Gu, and B. Zhang, "Geotectonic evolution and mineralization zone of gold deposits in western Qinling," Geotectonica et Metallogenia, vol. 21, no. 4, pp. 307-314, 1997.

[28] X. Ge, W. Ma, J. Liu, S. Ren, and S. Yuan, "Prospect of researches on regional tectonics of China," Geology in China, vol. 40, no. 1, pp. 61-73, 2013.

[29] J. Ren, Y. Chen, B. Niu, Z. Liu, and F. Liu, Tectonic Evolution and Mineralization of the Continental Lithosphere in Eastern China and Adjacent Regions, Science, Beijing, China, 1990.

[30] M. G. Zhai and M. Santosh, "Metallogeny of the North China Craton: link with secular changes in the evolving Earth," Gondwana Research, vol. 24, no. 1, pp. 275-297, 2013.

[31] K. McClay and T. Dooley, "Analog modeling of pull-apart Basins," AAPG Bulletin, vol. 81, no. 11, pp. 1804-1826, 1997.

[32] Shanxi Bureau of Geology and Mineral Resources, Regional Geology of Shanxi Province, Geological Publishing House, Beijing, China, 1989.

[33] Q. Hu, Y. Wang, R. Wang, J. Li, J. Dai, and S. Wang, "Oreforming time of the Erlihe $\mathrm{Pb}-\mathrm{Zn}$ deposit in the Fengxian-Taibai ore concentration area, Shaanxi Province: evidence from the $\mathrm{Rb}-\mathrm{Sr}$ isotopic dating of sphalerites," Acta Petrologica Sinica, vol. 28, no. 1, pp. 258-266, 2012.

[34] M. Tian, X. Yuan, Y. Zhang, and L. Wang, "Discussion of geological prospecting in Erlihe $\mathrm{Pb}$-Zn deposit, Fengxian," Mineral Resources and Geology, vol. 18, no. 2, pp. 134-138, 2004.

[35] R. Lv and H. Wei, "The geological characteristics and genetic investigation of Bafangshan stratabound polymetallic ores in Shanxi province," Journal of Chang'an University, vol. 12, no. 4, pp. 10-17, 1990.

[36] Y. Zhou, "Sedimentary geochemical characteristics of cherts of Danchi basin in Guangxi Province," Acta Sedimentologica Sinica, no. 3, pp. 75-83, 1990.

[37] Qinghai Bureau of Geology and Mineral Resources, Regional Geology of Qinghai Province, Geological Publishing House, Beijing, China, 1991.

[38] Gansu Bureau of Geology and Mineral Resources, Regional Geology of Gansu Province, Geological Publishing House, Beijing, China, 1989.

[39] Henan Bureau of Geology and Mineral Resources, Regional Geology of Henan Province, Geological Publishing House, Beijing, China, 1989.

[40] Anhui Bureau of Geology and Mineral Resources, Regional Geology of Anhui Province, Geological Publishing House, Beijing, China, 1987.

[41] G.-C. Zhao, Y.-H. He, and M. Sun, “The Xiong'er volcanic belt at the southern margin of the North China Craton: petrographic and geochemical evidence for its outboard position in the Paleo-Mesoproterozoic Columbia Supercontinent," Gondwana Research, vol. 16, no. 2, pp. 170-181, 2009.

[42] M. 1. Cui, L. C. Zhang, B. L. Zhang, and M. T. Zhu, "Geochemistry of $1.78 \mathrm{Ga}$ A-type granites along the Southern margin of the North China Craton: implications for Xiong'er magmatism during the break-up of the supercontinent Columbia," International Geology Review, vol. 55, no. 4, pp. 496-509, 2013.

[43] H. Li, Y. Zhou, L. Zhang et al., "Study on geochemistry and development mechanism of Proterozoic chert from Xiong'er Group in southern region of North China Craton," Acta Petrologica Sinica, vol. 28, no. 11, pp. 3679-3691, 2012.

[44] S. M. Mclennan, "Rare earth elements in sedimentary rocks: influences of provenance and sedimentary processes," Reviews in Mineralogy, vol. 21, pp. 169-200, 1989.
[45] S. R. Taylor and S. M. McLennan, The Continental Crust: Its Composition and Evolution, Blackwell Scientific Publications, Oxford, UK, 1985.

[46] R. W. Murray, M. R. B. T. Brink, D. C. Gerlach, G. P. Russ III, and D. L. Jones, "Rare earth, major, and trace element composition of Monterey and DSDP chert and associated host sediment: assessing the influence of chemical fractionation during diagenesis," Geochimica et Cosmochimica Acta, vol. 56, no. 7, pp. 2657-2671, 1992.

[47] K. Boström and M. N. A. Peterson, "The origin of aluminumpoor ferromanganoan sediments in areas of high heat flow on the East Pacific Rise," Marine Geology, vol. 7, no. 5, pp. 427-447, 1969.

[48] R. Sugisaki and T. Kinoshita, "Major element chemistry of the sediments on the central Pacific Transect, Wake to Tahiti, GH80-1 cruise," in Geological Survey of Japan Cruise Report, A. Mizuno, Ed., vol. 18, no. 293-312, 1982.

[49] P. A. Rona, "Hydrothermal mineralization at oceanic ridges," Canadian Mineralogist, vol. 26, pp. 431-465, 1988.

[50] G. Zhang and H. Cai, "Discussion on Origin of Dachang polymetallic ore deposit in Guangxi Province," Geological Review, vol. 33, no. 5, pp. 426-436, 1987.

[51] P. G. Spry and L. T. Bryndzia, Regional Metamorphism of Ore Deposits and Genetic Implications, VSP, Utrecht, The Netherlands, 1990.

[52] M. Adachi, K. Yamamoto, and R. Sugisaki, "Hydrothermal chert and associated siliceous rocks from the northern Pacific their geological significance as indication od ocean ridge activity," Sedimentary Geology, vol. 47, no. 1-2, pp. 125-148, 1986.

[53] R. W. Murray, "Chemical criteria to identify the depositional environment of chert: general principles and applications," Sedimentary Geology, vol. 90, no. 3-4, pp. 213-232, 1994.

[54] M. Baltuck, "Provenance and distribution of tethyan pelagic and hemipelagic siliceous sediments, pindos mountains, Greece," Sedimentary Geology, vol. 31, no. 1, pp. 63-88, 1982.

[55] Z. Tang, and Y. Zeng, "Petrology, geochemistry and origin of cherts in the uraniferous formations, Middle Silurian, West Qinling range," Acta Petrologica Sinica, no. 2, pp. 62-71, 1990.

[56] D. Wang, "Characteristics and origin of siliceous rocks from Yarlung Zangbo deep fracture in Tibet, China," in Tibetan Plateau Comprehensive Survey Group of Chinese Academy of Science, Sedimentary Rocks in South Tibet, pp. 1-86, Science Press, Beijing, China, 1981.

[57] S. S. Sun, "Lead isotopic study of young volcanic rocks from mid-ocean ridge, ocean islands and island arcs," Philosophical Transactions of the Royal Society of London, vol. A297, no. 1431, pp. 409-445, 1980.

[58] A. D. Saunders and J. Tarney, "Geochemical characteristics of basaltic volcanism within back-arc basin," in Marginal Basin Geology, B. P. Kokelaar and M. F. Howells, Eds., pp. 59-76, The Geological Society, London, UK, 1984.

[59] B. L. Weaver and J. Tarney, "Empirical approach to estimating the composition of the continental crust," Nature, vol. 310, no. 5978, pp. 575-577, 1984.

[60] V. Marchig, H. Gundlach, P. Möller, and F. Schley, "Some geochemical indicators for discrimination between diagenetic and hydrothermal metalliferous sediments," Marine Geology, vol. 50, no. 3, pp. 241-256, 1982.

[61] G. H. Girty, D. L. Ridge, C. Knaack, D. Johnson, and R. K. AlRiyami, "Provenance and depositional setting of paleozoic chert and argillite, Sierra Nevada, California," Journal of Sedimentary Research, vol. 66, no. 1, pp. 107-118, 1996. 
[62] J. M. Peter and S. D. Scott, "Mineralogy, composition, and fluidinclusion microthermometry of seafloor hydrothermal deposits in the Southern Trough of Guaymas Basin, Gulf of California," Canadian Mineralogist, vol. 26, pp. 567-587, 1988.

[63] K. Boström, T. Kraemer, and S. Gartner, "Provenance and accumulation rates of opaline silica, $\mathrm{Al}, \mathrm{Ti}, \mathrm{Fe}, \mathrm{Mn}, \mathrm{Cu}, \mathrm{Ni}$ and $\mathrm{Co}$ in Pacific pelagic sediments," Chemical Geology, vol. 11, no. 1-2, pp. 123-148, 1973.

[64] K. M. Yarincik, R. W. Murray, T. W. Lyons, L. C. Peterson, and G. H. Haug, "Oxygenation history of bottom waters in the Cariaco Basin, Venezuela, over the past 578,000 years: Results from redox-sensitive metals (Mo, V, Mn, and Fe)," Paleoceanography, vol. 15, no. 6, pp. 593-604, 2000.

[65] S. Sun, Q. Zhang, and Q. Qin, "Sedimentary geochemistry significance of $\mathrm{Sr} / \mathrm{Ba}-\mathrm{V} / \mathrm{Ni}$," in New Exploration of Mineral, Rock and Geochemistry, Z. Ouyang, Ed., pp. 128-130, Earthquake Publishing House, Beijing, China, 1993.

[66] Y. Sui, G. Wu, and C. Qi, "Mafic-ultramafic rock association and the mineralization-forming specialization of Cr-Ni deposit," Journal of Jiling University, vol. 34, no. 2, pp. 201-205, 2004.

[67] R. W. Murray, M. R. Buchholtz Ten Brink, D. C. Gerlach, G. P. Russ III, and D. L. Jones, "Rare earth, major, and trace elements in chert from the Franciscan Complex and Monterey Group, California: assessing REE sources to fine-grained marine sediments," Geochimica et Cosmochimica Acta, vol. 55, no. 7, pp. 1875-1895, 1991.

[68] R. W. Murray, M. R. Buchholtz Ten, D. L. Brink, D. C. Gerlach, and P. G. Russ, "Rare earth elements as indicators of different marine depositional environments in chert and shale," Geology, vol. 18, no. 3, pp. 268-271, 1990.

[69] R. W. Murray, M. R. Buchholtzten Brink, H. J. Brumsack, D. C. Gerlach, and G. P. Russ III, "Rare earth elements in Japan Sea sediments and diagenetic behavior of Ce/Ce $*$ : results from ODP Leg 127," Geochimica et Cosmochimica Acta, vol. 55, no. 9, pp. 2453-2466, 1991.

[70] H. Elderfield, R. Upstill-Goddard, and E. R. Sholkovitz, "The rare earth elements in rivers, estuaries, and coastal seas and their significance to the composition of ocean waters," Geochimica et Cosmochimica Acta, vol. 54, no. 4, pp. 971-991, 1990.

[71] A. Michard, F. Albarède, G. Michard, J. F. Minster, and J. L. Charlou, "Rare-earth elements and uranium in hightemperature solutions from east pacific rise hydrothermal vent field (13 ○N)," Nature, vol. 303, no. 5920, pp. 795-797, 1983.

[72] J. F. Scott and S. P. S. Porto, "Longitudinal and transverse optical lattice vibrations in quartz," Physical Review, vol. 161, no. 3, pp. 903-910, 1967.

[73] Y. Ke and H. Dong, Analysis Chemistry: The Third Volume: Analysis spectrum, Chemical Industry Press, Beijing, China, 2nd edition, 1998.

[74] M. Ostroumov, E. Faulques, and E. Lounejeva, "Raman spectroscopy of natural silica in Chicxulub impactite, Mexico," Comptes Rendus Geoscience, vol. 334, no. 1, pp. 21-26, 2002.

[75] M. Yoshikawa, K. Iwagami, N. Morita, T. Matsunobe, and H. Ishida, "Characterization of fluorine-doped silicon dioxide film by Raman spectroscopy," Thin Solid Films, vol. 310, no. 1-2, pp. 167-170, 1997.

[76] B. Y. Lynne, K. A. Campbell, J. N. Moore, and P. R. L. Browne, "Diagenesis of 1900-year-old siliceous sinter (opal-A to quartz) at Opal Mound, Roosevelt Hot Springs, Utah, U.S.A," Sedimentary Geology, vol. 179, no. 3-4, pp. 249-278, 2005.

[77] S. Bernard, K. Benzerara, O. Beyssac et al., "Exceptional preservation of fossil plant spores in high-pressure metamorphic rocks," Earth and Planetary Science Letters, vol. 262, no. 1-2, pp. 257-272, 2007.

[78] P. Xu, R. Li, Y. Wang, Z. Wang, and Y. Li, Raman Spectrum in the Earth Science, Shanxi Science and Technology Press, Xian, China, 1996.

[79] F. Pan, X. Yu, X. Mo et al., "Raman active vibrations of aluminosilicates," Spectroscopy and Spectral Analysis, vol. 26, no. 10, pp. 1871-1875, 2006.

[80] Y. Zhou, W. Fu, Z. Yang et al., "Microfabrics of chert from Yarlung Zangbo Suture Zone and southern Tibet and its geological implications," Acta Petrologica Sinica, vol. 22, no. 3, pp. 742-750, 2006.

[81] H. Li, M. Zhai, L. Zhang et al., "Study on microarea characteristics of calcite in late archaean BIF from Wuyang area in south margin of north China craton and its geological significances," Spectroscopy and Spectral Analysis, vol. 33, no. 11, pp. 3061-3065, 2013.

[82] T. Arguirov, T. Mchedlidze, V. D. Akhmetov et al., "Effect of laser annealing on crystallinity of the $\mathrm{Si}$ layers in $\mathrm{Si} / \mathrm{SiO}_{2}$ multiple quantum wells," Applied Surface Science, vol. 254, no. 4, pp. 1083-1086, 2007.

[83] B. Champagnon, G. Panczer, C. Chemarin, and B. HumbertLabeaumaz, "Raman study of quartz amorphization by shock pressure," Journal of Non-Crystalline Solids, vol. 196, pp. 221226, 1996.

[84] M. A. Carpenter, E. K. H. Salje, A. Graeme-Barber, B. Wruck, M. T. Dove, and K. S. Knight, "Calibration of excess thermodynamic properties and elastic constant variations associated with the $\alpha \longleftrightarrow \beta$ phase transition in quartz," American Mineralogist, vol. 83, no. 1-2, pp. 2-22, 1998.

[85] B. Olinger and P. M. Halleck, "The compression of $\alpha$ quartz," Journal of Geophysical Research, vol. 81, no. 32, pp. 5711-5714, 1976.

[86] S. Shen and Z. Li, Materials Technology of Minerals and Rocks, China University of Geosciences Press, Wuhan, China, 2005.

[87] D. Ge, H. Tian, and R. Zeng, Oryctognosy Concise Tutorial, Geological Press, Beijing, China, 2006.

[88] O. W. Flörke, B. Köhler-Herbertz, K. Langer, and I. Tönges, "Water in microcrystalline quartz of volcanic origin: agates," Contributions to Mineralogy and Petrology, vol. 80, no. 4, pp. 324-333, 1982.

[89] G. Hirth and J. Tullis, "Dislocation creep regimes in quartz aggregates," Journal of Structural Geology, vol. 14, no. 2, pp. 145159, 1992.

[90] M. Stipp, H. Stünitz, R. Heilbronner, and S. M. Schmid, “The eastern Tonale fault zone: a "natural laboratory" for crystal plastic deformation of quartz over a temperature range from 250 to $700^{\circ}$ C," Journal of Structural Geology, vol. 24, no. 12, pp. 18611884,2002

[91] C. W. Passchier and R. A. J. Trouw, Microtectonics, Springer, Berlin, Germany, 2nd edition, 2005.

[92] Y. Zhou, W. Fu, Z. Yang et al., "Geochemical characteristics of Mesozoic chert from Southern Tibet and its petrogenic implications," Acta Petrologica Sinica, vol. 24, no. 3, pp. 600-608, 2008.

[93] F. Han and R. W. Harrison, "Evidence for exhalative origin for rocks and ores of the Dachang tin polymetallic field: the orebearing formation and hydrothermal exhalative sedimentary rocks," Mineral Deposits, vol. 8, no. 2, pp. 25-40, 1989.

[94] S. Zhang, T. Li, and L. Wang, "Geochemistry and genesis of the changkeng large superlarge gold silver deposit, guangdong province," Mineral Deposits, vol. 17, no. 2, pp. 125-134, 1998. 
[95] H. Liang, H. Yu, P. Xia, and X. Wang, "Characteristics and genesis of Changkeng gold-hosting siliceous rock in the rim of southwestern Sanshui Basin, middle Guangdong Province, China," Geochimica, vol. 38, no. 2, pp. 195-201, 2009.

[96] E. C. Dapples, "Silica as an agent in diagenesis," in Diagenesis in Sediments, G. Larsen and G. V. Chilingar, Eds., Diagenesis in aediments, pp. 323-342, Diagenesis in Sediments, Amsterdam, 1967.

[97] J. Liu and M. Zhen, "New origin of siliceous rocks-hydrothermal sedimentation," Acta Geologica Sichuan, vol. 11, no. 4, pp. 251-254, 1991.

[98] C. Feng and J. Liu, "The investive actuslity and mineralization significance of cherts," World Geology, vol. 20, no. 2, pp. 119-123, 2001.

[99] H. Li, Chert sedimentary system and its indications on tectonic evolution, petrogenesis and mineralization in northern and southern margins of Yangtze Platform, China [Ph.D. thesis], Sun Yat-Sen University, GuangZhou, China, 2012.

[100] K. B. Krauskopf, "Factors controlling the concentrations of thirteen rare metals in sea-water," Geochimica et Cosmochimica Acta, vol. 9, no. 1-2, pp. 1-32, 1956.

[101] S. E. Calvert, "Sedimentary geochemistry of silicon," in Silicon Geochemistry and Biogeochemistry, S. R. Aston, Ed., pp. 143-186, Academic Press, London, UK, 1983.

[102] G. Zhang, Q. Meng, and S. Lai, "Tectonics and structure of Qinling orogenic belt," Science in China B, vol. 25, no. 9, pp. 9941003, 1995.

[103] Q. Meng, G. Zhang, Z. Yu, and Z. Mei, "Late Paleozoic sedimentation and tectonics of rift and limited ocean basin at southern margin of the Qinling," Science China: Earth Sciences, vol. 26, pp. 28-33, 1996.

[104] S. Lai, G. Zhang, and X. Pei, "Geochemistry of the Pipasi ophiolite in the Mianlue suture zone, South Qinling, and its tectonic significance," Geological Bulletin of China, vol. 21, no. 8-9, pp. 465-470, 2002.

[105] K. A. Kormas, M. K. Tivey, K. von Damm, and A. Teske, "Bacterial and archaeal phylotypes associated with distinct mineralogical layers of a white smoker spire from a deep-sea hydrothermal vent site (9०N, East Pacific Rise)," Environmental Microbiology, vol. 8, no. 5, pp. 909-920, 2006.

[106] G. Racki and F. Cordey, "Radiolarian palaeoecology and radiolarites: is the present the key to the past?" Earth Science Reviews, vol. 52, no. 1-3, pp. 83-120, 2000.

[107] Y. Furukawa and S. E. O’Reilly, "Rapid precipitation of amorphous silica in experimental systems with nontronite (NAu-1) and Shewanella oneidensis MR-1," Geochimica et Cosmochimica Acta, vol. 71, no. 2, pp. 363-377, 2007.

[108] Y. Li, K. O. Konhauser, D. R. Cole, and T. J. Phelps, "Mineral ecophysiological data provide growing evidence for microbial activity in banded-iron formations," Geology, vol. 39, no. 8, pp. 707-710, 2011.

[109] I. M. Samson and M. J. Russell, "Genesis of the silvermines zinclead barite deposit, Ireland: fluid inclusion and stable isotope evidence.," Economic Geology, vol. 82, no. 2, pp. 371-394, 1987.

[110] D. R. Cooke, S. W. Bull, R. R. Large, and P. J. McGoldrick, "The importance of oxidized brines for the formation of Australian Proterozoic stratiform sediment-hosted $\mathrm{Pb}-\mathrm{Zn}$ (sedex) deposits," Economic Geology, vol. 95, no. 1, pp. 1-18, 2000.

[111] R. W. Hutchinson, "Volcanogenic sulfide deposits and their metallogenic significance," Economic Geology, vol. 68, no. 8, pp. 1223-1246, 1973.
[112] J. K. Mortensen, B. V. Hall, T. Bissig et al., "Age and paleotectonic setting of volcanogenic massive sulfide deposits in the Guerrero terrane of central Mexico: constraints from $\mathrm{U}-\mathrm{Pb}$ Age and $\mathrm{Pb}$ isotope studies," Economic Geology, vol. 103, no. 1, pp. 117-140, 2008.

[113] S. Wu, Study of Hydrothermal Chimneys in the Mariana Trough, China Ocean Press, Beijing, China, 1995.

[114] Z. Hou, F. Han, L. Xia et al., Modern and Ancient Submarine Hydrothermal Mineralized Activities, Geological Publishing House, Beijing, China, 2003.

[115] J. W. Lydon, "Chemical parameters controlling the origin and deposition of sediment-hosted stratiform lead-zinc deposits," in Short Course in Sediment Hosted Stratiform Lead-Zinc Deposits, D. F. Sangster, Ed., pp. 175-250, Mineralogical Association of Canada, Victoria, Canada, 1983.

[116] M. J. Russell, "Major sediment-hosted zinc + lead deposits: formation from hydrothermal convection cells that deepen during crustal extension," in Short Course in Sediment Hosted Stratiform Lead-Zinc Deposits, D. F. Sangster, Ed., pp. 251-282, Mineralogical Association of Canada, Victoria, Canada, 1983.

[117] D. L. Huston, B. Stevens, P. N. Southgate, P. Muhling, and L. Wyborn, "Australian $\mathrm{Zn}-\mathrm{Pb}$-Ag ore-forming systems: a review and analysis," Economic Geology, vol. 101, no. 6, pp. 1117-1157, 2006.

[118] D. L. Leach, D. C. Bradley, D. Huston, S. A. Pisarevsky, R. D. Taylor, and S. J. Gardoll, "Sediment-hosted lead-zinc deposits in earth history," Economic Geology, vol. 105, no. 3, pp. 593-625, 2010.

[119] F. N. Spiess, K. C. Macdonald, T. Atwater et al., "East Pacific Rise: hot springs and geophysical experiments," Science, vol. 207, no. 4438, pp. 1421-1433, 1980.

[120] S. Qi, Y. Li, Z. Zeng, W. Liang, H. Wei, and X. Ning, LeadZinc (Copper) Deposits of SEDEX Type in Qinling Mountains, Geological Publishing House, Beijing, China, 1993.

[121] H. D. Holland, "Gangue minerals in hydrothermal system," in Geochemistry of Hydrothermal Ore Deposits, H. L. Barners, Ed., pp. 382-436, John Wiley \& Sons, New York, NY, USA, 1967.

[122] P. A. Rona, K. Boström, and S. Epstein, "Hydrothermal quartz vug from the Mid-Atlantic Ridge," Geology, vol. 8, no. 12, pp. 569-572, 1980. 

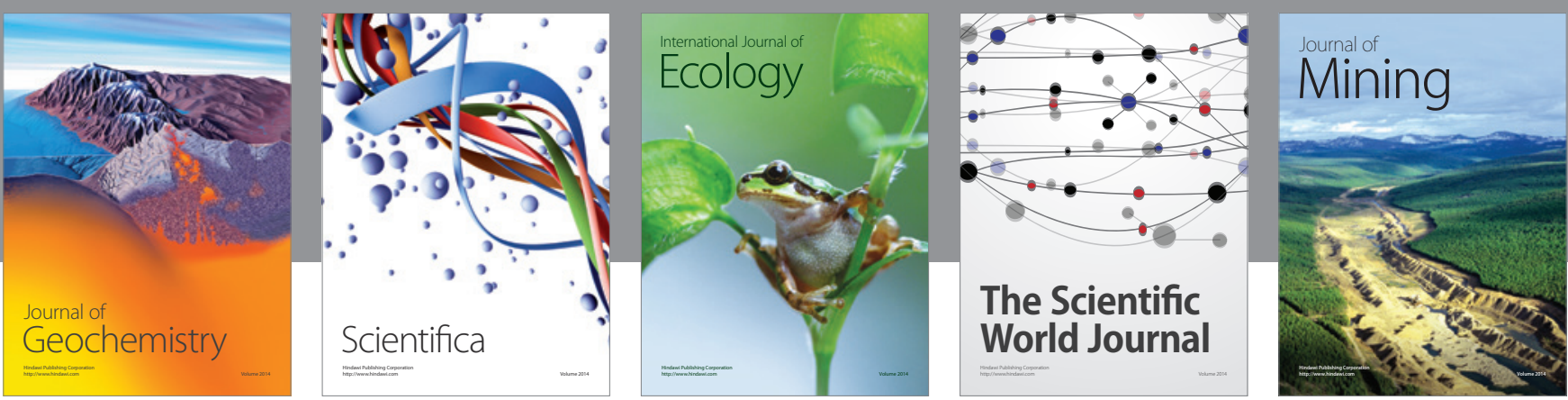

The Scientific World Journal
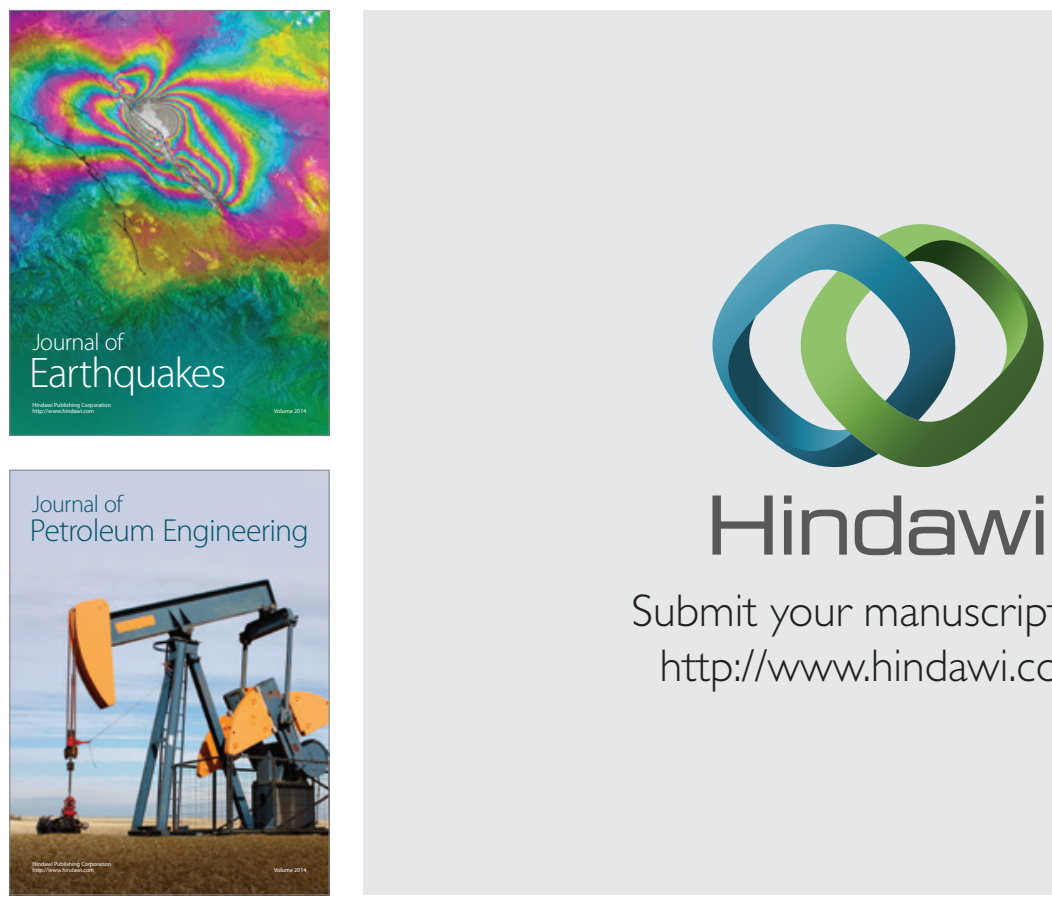

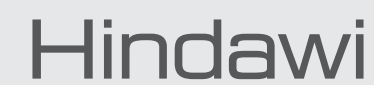

Submit your manuscripts at

http://www.hindawi.com
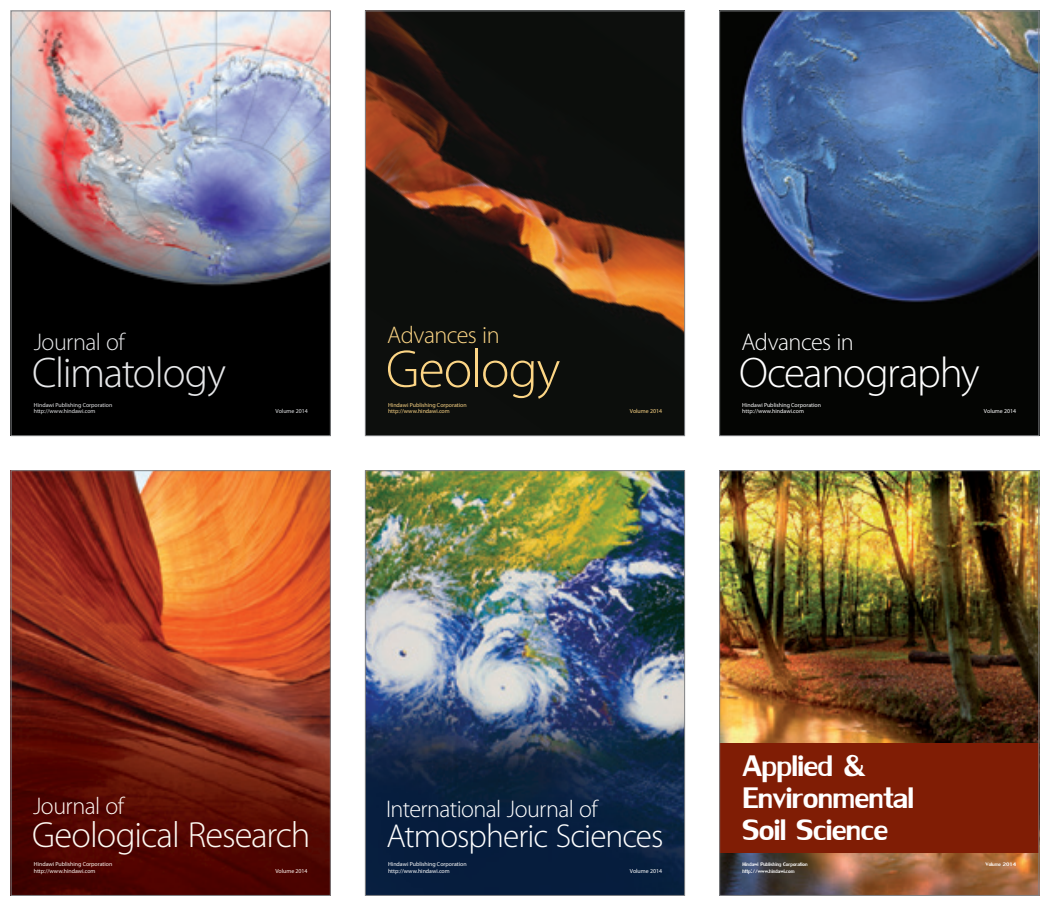
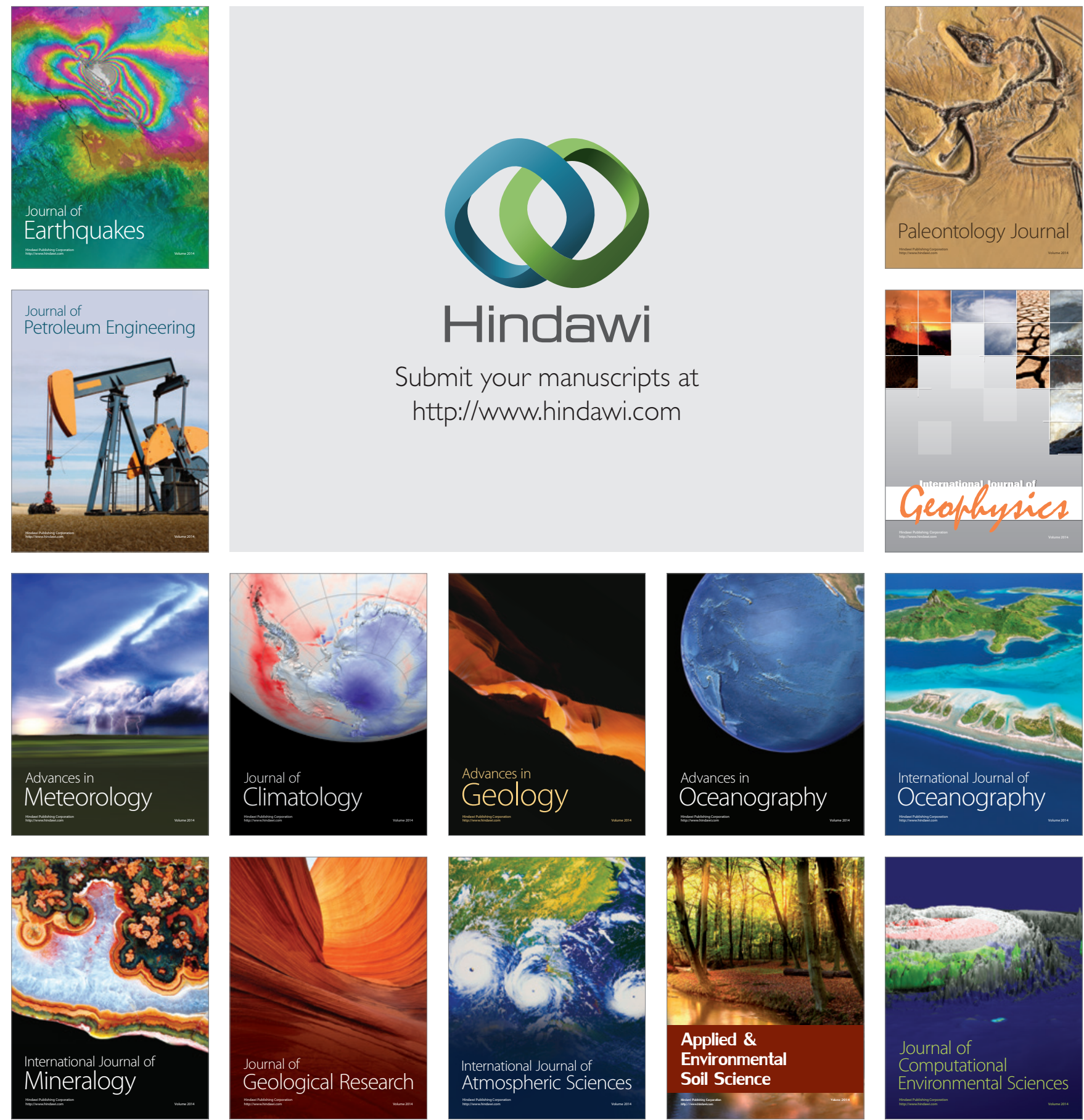